\title{
Anthropogenic Land Use/Cover Change Detection And Its Impacts On Hydrological Responses of Genale Catchment, Ethiopia
}

\section{Tufa Feyissa Negewo ( $\square$ tufa1886@gmail.com )}

Indian Institute of Technology, Guwahati https://orcid.org/0000-0003-2765-2474

\section{Arup Kumar Sarma}

Indian Institute of Technology, Guwahati

\section{Research Article}

Keywords: Land use/cover, Genale watershed, Image processing, GIS, Change detection, Satellite imagery, SWAT, Hydrological responses

Posted Date: October 19th, 2021

DOl: https://doi.org/10.21203/rs.3.rs-938182/v1

License: (c) (i) This work is licensed under a Creative Commons Attribution 4.0 International License.

Read Full License 


\title{
Anthropogenic Land Use/Cover Change Detection and Its Impacts on Hydrological Responses of Genale Catchment, Ethiopia
}

\author{
Tufa Feyissa Negewo ${ }^{1 *}$, and Arup Kumar Sarma² \\ 1* Ph.D. Research Candidate, Department of Civil Engineering, Indian Institute of Technology, Guwahati 781039, \\ Assam, India, E-mail: tufa@iitg.ac.in; tufa1886@gmail.com \\ ${ }^{2}$ Prof., Department of Civil Engineering, Indian Institute of Technology, Guwahati 781039, Assam, India, E-mail: \\ aks@iitg.ac.in
}

\begin{abstract}
Change in land use land-cover (LULC) is a paramount dynamic present-day challenging landscape process
\end{abstract} capable of altering the hydrological responses in the catchment. As the land use planners require updated and highresolution land resources information, understanding land cover change-induced status due to anthropogenic activities is significant. In this study, multitemporal cloud-free satellite imageries for periods (1990, 2002, and 2013) were used to quantify the spatiotemporal dynamics of land-use change detection and examine the effect on hydrological response using Geographical Information System (GIS) and Soil and Water Assessment Tool (SWAT) model in the Genale watershed, Ethiopia. The model performance was evaluated through sensitivity, uncertainty analysis, calibration, and validation process. The analysis of LULC change patterns for the area under study over 24 years showed that most parts of the green forest, barren land, and range shrubs were changed into agriculture, built up, wetlands, and water body with an increase of agriculture by $60 \%$, built up $68 \%$, pasture $37 \%$, range shrubs $9 \%$, and water body $57 \%$ over (1990 to 2013), which increased surface runoff, water yield, and sediment yield in the catchment. Significant changes in hydrological elements were observed at the sub-basins scale, mainly associated with the uneven spatial distribution of LULC changes compared to the whole watershed. The impacts of individual LULC change on hydrological response show a good correlation matrix. The regional government needs to modify land development policies and sustainable plans for examining LULC change detection using satellite imagery to avoid illegal land expansion activities.

Keywords: Land use/cover, Genale watershed, Image processing, GIS, Change detection, Satellite imagery, SWAT, Hydrological responses

\section{Introduction}

The land is one of the non-renewable/dynamic resources, and mapping of land-use land-cover (LULC) is fundamental for designing and developing land, water resources with appropriate tools (Manjunatha and Basavarajappa 2020). Image accuracy assessment is an essential step in the LULC map classification process. The target is to quantitatively evaluate how effectively pixels were grouped into the correct feature classes in the area under investigation (Bharatkar and Patel 2013; Kaya and Görgün 2020). The accuracy assessment determines how well a classification worked 
between the ground truth data and classified image by pixels to interpret the use of someone else's classification. The analysis revealed the classification is that all pixels in an image/map are assigned to particular classes/themes, which results in a classified image that is a thematic map of the original image (Hussain et al. 2019; Abdelkareem et al. 2017) Supervised classification is the approach most often used for the quantitative investigation of remote sensing image data. The concept of separating the spectral domain into different regions associated with the ground truth covers classes of interest to a particular classification by features/pixels present in a scene (Elimy et al. 2020). Most investigator prefers it because it generally gives more class definitions and higher accuracy than unsupervised techniques (Adam 2011). Supervised classification uses a maximum likelihood classifier principle on statistical decision making, and then classification is done by overlapping signatures and pixels input bands to the class of highest probability (Bharatkar and Patel 2013). The Maximum Likelihood decision rule is still one of the most widely used supervised classification algorithms, and its accuracy is well documented (Rwanga and Ndambuki 2017). The major elements of a sampling technique include sampling units (pixels/features or polygons), sampling design, and sample size in image processing. Bharatkar and Patel (2013) suggest that at least 50 coaching pixels per class are meaningful during image classification. If the area of interest exceeds $500 \mathrm{~km}^{2}$ or the number of LULC categories exceeds 12 , then a minimum of 75 - 100 training feature classes should be taken per class. The idea of quantitative accuracy assessment is to identify the sources of errors. Apart from classification errors, other sources of errors, such as interpretation errors, position errors resulting from the registration, and low quality of training samples, all affect classification accuracy. The most common means of asserting classification accuracy is to compare a class by class basis the relation between known reference data (ground truth) from google earth and the corresponding results of an evaluated classification (Adam 2011; Abdelkareem et al. 2017; Erasu 2017). In the LULC map, classification error occurs when a pixel (or feature class) associated with one category is assigned. The name of accuracy classification error arranged in a square matrix establishes a standard category representing the end product of a created map, which helps find a site-specific error in the process known as an error/confusion matrix. The most common/suited accuracy classification error estimator, the confusion matrices/overall accuracy, and Kappa coefficient $\left(K_{\text {hat }}\right)$ measure statistical analysis for accuracy agreement between ground truth data and evaluated classification. Kappa coefficient analysis is accepted as a powerful technique for monitoring a single confusion matrix and for comparing the differences between individual error matrices (Rwanga and Ndambuki 2017).

The use of remote sensing and GIS techniques is delightful to meet the mapping and monitoring changes over time to 64 point out the impact of built-up and agriculture on the forest and natural heritage of the waterbody (Tomar 2017; Erasu 2017). LULC is a dynamic aspect that modifies through time and space due to human-made burden (anthropogenic) and development (Gwenzi 2014; Guse et al. 2015). Evaluating the present LULC and its unscientific change is good to know for urban planners, policymakers, natural resources managers, and remote sensing action is an effective mechanism for detecting and analyzing temporal changes and should be monitored regularly as it causes irreversible impacts on the environment (Navin and Agilandeeswari 2019; Manjunatha and Basavarajappa 2020). The detailed process of LULC change detection is essential in gathering the specific information about the quantitative change of globally due to a high rate of climatic changes, industrialization, urbanization, rapid population growth, and the 
growing socio-economic resources (Negewo and Sarma 2021a; Sansare and Mhaske 2020). The current target is to detect LULC pattern changes and their aerial extent due to different socio-economic factors in the study area. LULC changes on the earth's surface are generally divided into land use and land cover, which are two concepts and are usually used interchangeably. LULC dynamic change affects the hydrological process (runoff generation, water yield, sediment yield, streamflow, etc.) with the increasing urbanization \& agriculture.

The consequences of different LULC are required to review sustainable water resources management, land use planning, and development (Sansare and Mhaske 2020). Generally, most of the registered LULC changes were the results of the anthropogenic activities achieved to satisfy the immediate needs of human beings. These spontaneously rapid LULC changes bring adverse impacts on the environment and water resources potential of a nation.

In the Horn of African countries, primary in Ethiopia, water resources management and planning challenges are the extreme hydrological variability and seasonality of its most fascinating surface and groundwater resources. However, the primary water resources contributor for the Genale watershed is mainly groundwater (Negewo and Sarma 2021a). Erosion of soil by water action is also one of the major restraints of agricultural production in Ethiopian highlands that affects productivity and the primary sources of reservoir sedimentation (Negewo and Sarma 2021b; Negewo and Sarma, In press). Although the country is blessed with sufficient water resources, recent $21^{\text {st- }}$ century natural forest cover has been dismissed and causes land degradation and water flow extremes (Negewo and Sarma In press; Choto and Fetene 2019). In this view, LULC plays a significant role in water transport in the hydrologic system and chiefly aids in reducing overland flows. As a result of its effect on evaporation, transpiration, and solar radiation interception, LULC is a propulsive factor in the energy balance equation in the hydrological process (Tadesse et al. 2015). Genale watershed is one of Ethiopia's Genale Dawa River Basin system sub-basins, with different tributaries, different distributaries, and dendritic drainage patterns.

The watershed is a degraded field with anthropogenic land use activities with agricultural on steep slopes and builtup areas (Negewo and Sarma, In press). In the Genale watershed, no research has been done to investigate the impacts of LULC change on the hydrological response of the watershed. Therefore, the dynamics of LULC change in this catchment require hydrologic modeling that provides a helpful tool in water resources management $\&$ plan for many years and is usually used to predict land-use impacts on streamflow and sediment yield. For water resources, stakeholders, and decision-makers, knowing how and how much LULC changes will influence water availability at the sub-basin/HRUs scale is more important for planning appropriate soil and water mitigation measures (Aragaw et al. 2021). Therefore, research is required at the sub-basin/HRUs scale to recognize the hydrological response conditions to LULC changes. Notably, water resources for energy generation may face severe problems due to changes in hydrological regimes, particularly increases in sediment yield of the watershed due to LULC change. The SWAT model has been used to predict land use/cover change impacts on soil and water losses. The results illustrate that even nearly limited land-use change, from forest to arable/cultivable land or vice versa, significantly affects regional and local soil erosion rates and sediment supply to rivers (Huang and Lo 2015; VanRompaey et al. 2002). The SWAT model's quantitative hydrological investigation due to land use/cover change is a good approach for identifying the LULC change detection and impact of land-use change on the hydrological process of the Genale watershed (Li 2020; Kumar et al. 2017; El Harraki et al. 2021). This suggests quantitative knowledge allows stakeholders and decision- 
makers to make better land, soil, and water resource management and plan choices. Besides quantifying the gross impacts of LULC changes on hydrological responses by applying a hydrological model, it is also informative to evaluate the effect and contribution of individual LULC change on different hydrological components of a catchment

113 (Gashaw et al. 2018). The multivariate statistical design is helpful to explore the interaction of each LULC type

114 (independent variable) with different hydrological responses (dependent variables) and confirm whether the observed

115 LULC change is significant enough to induce the change in hydrological processes. It can be applied to address the

116 LULC class responsible for changing hydrological components (Shawul et al. 2019). Moreover, this approach is

117 applicable for solving multicollinearity problems, which occur when at least two predictors (independent variables)

118 in the model are correlated. The study is interacting with the individual LULC changes to hydrological elements using

119 multivariate statistical correlation to quantify the contribution of changes in hydrological responses.

120 The main spotlight of this study is (1) Appraisal of image processing/assessment of image classification accuracy, (2) 121 to examine the LULC change detection of different periods, (3) to evaluate the impacts of different LULC changes on 122 hydrological responses in Genale watershed, Ethiopia.

\section{Description of the Study Area}

Genale catchment $\left(54,942 \mathrm{Km}^{2}\right)$ was situated in Genale Dawa River Basin in Ethiopia, covering Oromia, SNNP, and Somali regions. The catchment gets its first maximum rainfall during spring (March to May) and secondary maximum rainfall during autumn (September to November). The yearly average precipitation experienced in the study area is about $810 \mathrm{~mm}$, and the rainfall distribution in a watershed ranges from 300 to $1302 \mathrm{~mm}$ per year. The Genale River joins the Dawa River at the Dolo Ado border, which then forms Genale Dawa River Basin is geographically located between $4^{\circ} 16^{\prime}$ to $7^{\circ} 02^{\prime}$ North and $39^{\circ} 00^{\prime}$ to $42^{\circ} 00^{\prime}$ East. The Monthly temperature ranges from $14.5^{\circ} \mathrm{C}$ to $24.6{ }^{\circ} \mathrm{C}$, with an average of $19.5{ }^{\circ} \mathrm{C}$. The maximum and minimum elevation of the study area is 4280 and $176 \mathrm{~m}$, respectively (Negewo and Sarma 2021b). Fig. 1 the study area map with the Digital Elevation Model (DEM) extracted from the Genale Dawa River Basin and Ethiopia map. The weather data needed for the study was collected from the 'National Meteorological Agency of Ethiopia, ' which covered from 1987 to 2013 for different measure stations and GMS (Global Meteorological Stations 1, 2,3 ..8) detailed in Fig. 1. The streamflow and sediment data were taken from the then transferred to the outlet as calibration was done at the outlet location. 


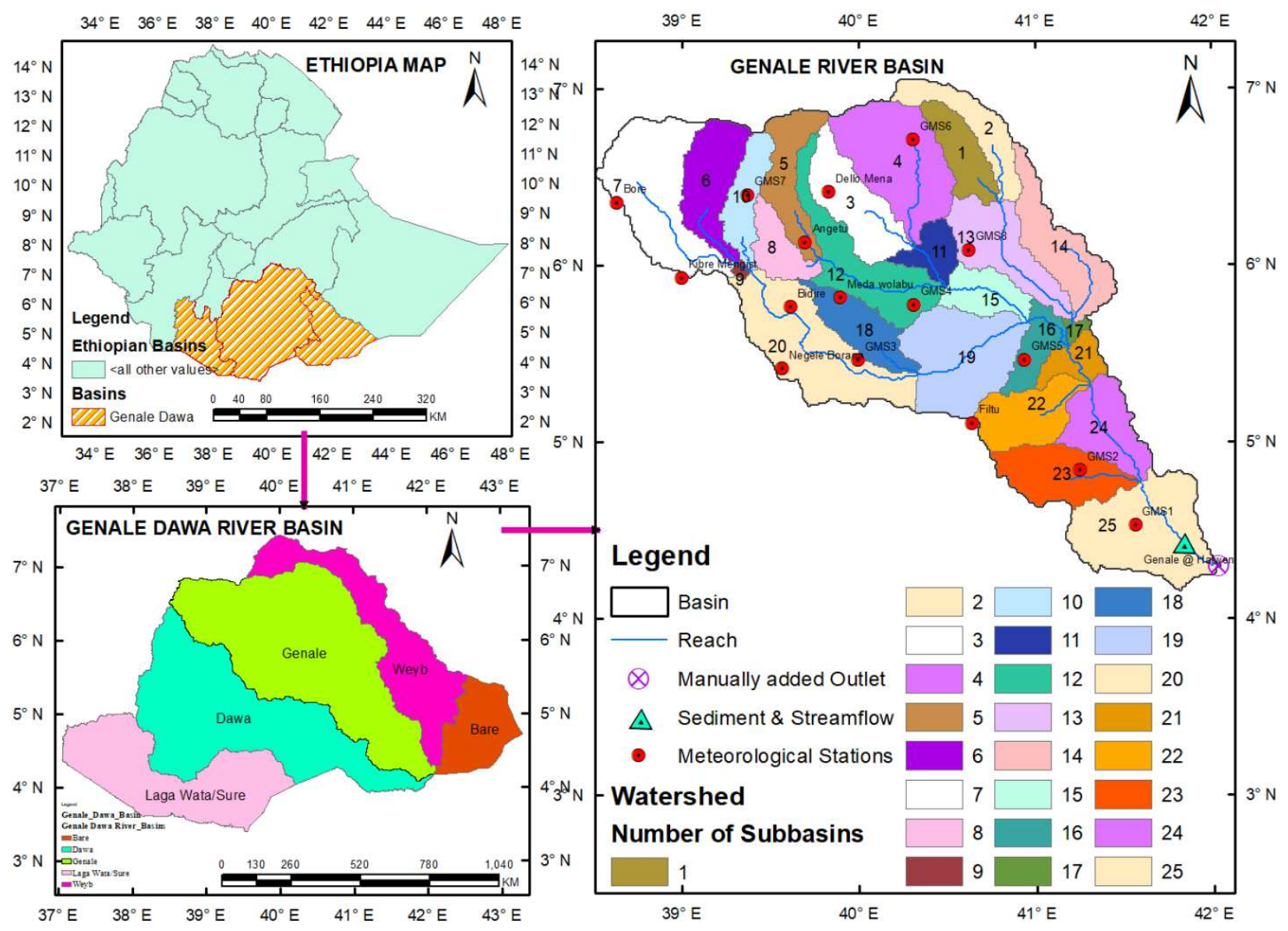

141 Fig. 1 The study area of Genale watershed, Ethiopia

\section{Materials and methodology}

145 The study aims analysis of land use/cover change by classifying satellite imageries of the Genale watershed. The

146 criterion used to monitor LULC change detection was the 24-year data collection period from 1990 to 2013. The 147 mechanism contains four stages: 1) pre-processing (image rectification and restoration), 2) image classification, 3) 148 post-processing (information extraction), and 4) land-use change detection. Remote sensing and GIS are essential for 149 producing land use/cover maps through image classification.

150 In this finding, the Soil and Water Assessment Tool (SWAT) model interfaced with GIS was used to inspect the impacts of LULC change on hydrological responses of the catchment (Fig. 2). 


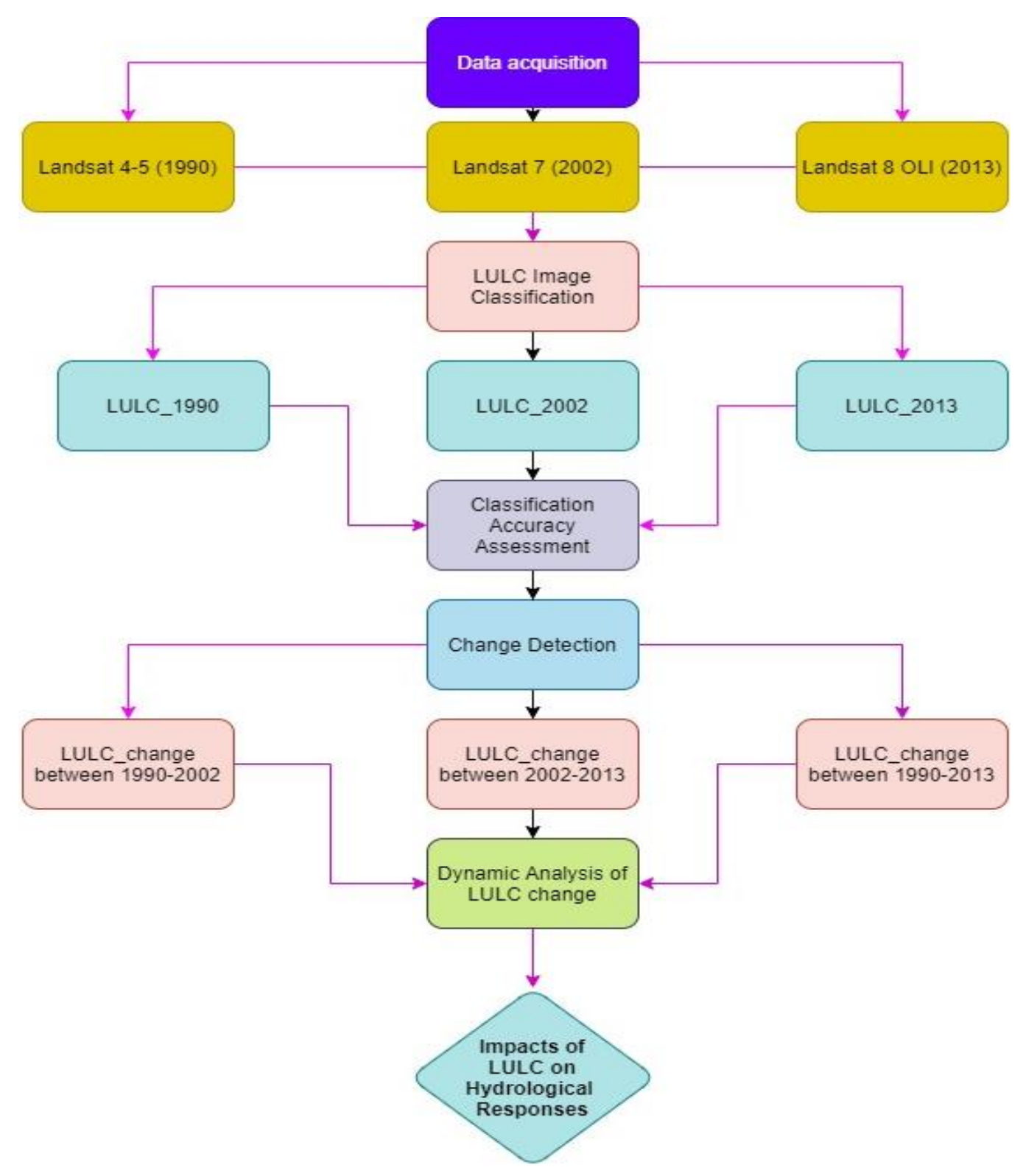

154 Fig. 2 Flow chart and methodology of the study area

156 Data sources, preparation, and image processing

158 For the present study, Landsat 4-5, Landsat-7, and Landsat 8 OLI (operational land imager) spatial resolution of $90 \mathrm{~m}$ 159 The USGS (united states geological survey) earth explorer database system was used for generating LULC maps.

160 Processing satellite imageries before detection changes are imperative and have a unique aspiration to build a more 161 direct association between the biophysical development on the ground and the data acquisition (Coopin et al. 2004).

162 The main aim of image processing and classification is to automatically categorize all pixels in an image into LULC 163 categories to draw out helpful, confined information. Image classification was done to designate multi-spectral 
signatures from the landsat datasets to different years of LULC. LULC types are frequently mapped from digital, remotely sensed data through supervised digital image classification (Campbell and Wynne, 2011).

Table 1 Detail sources of satellite imageries used in this study with the output file are in GeoTIFF format

\begin{tabular}{|c|c|c|c|c|c|c|}
\hline $\begin{array}{l}\text { Landsat } \\
\text { satellites } \\
\text { Type }\end{array}$ & Sensor onboard & Availability & $\begin{array}{l}\text { Path/Row } \\
\text { (Mosaiced is done } \\
\text { respectively) }\end{array}$ & $\begin{array}{l}\text { Pixel } \\
\text { size } \\
(\mathrm{m})\end{array}$ & $\begin{array}{l}\text { No of } \\
\text { spectral } \\
\text { bands }\end{array}$ & $\begin{array}{l}\text { Date of } \\
\text { acquisition }\end{array}$ \\
\hline Landsat 8 & $\begin{array}{l}\text { OLI and TIRS } \\
\text { (Thermal Infrared } \\
\text { Sensor) Level-1 }\end{array}$ & $\begin{array}{l}\text { February of } \\
2013 \text { to } \\
\text { present }\end{array}$ & $\begin{array}{l}(166),(167) \&(168) / \\
(56 \& 57),(55,56 \& 57) \\
\&(55 \& 56)\end{array}$ & 90 & 11 & $\begin{array}{l}\text { December 10, } \\
2013\end{array}$ \\
\hline Landsat 7 & $\begin{array}{l}\text { Enhanced Thematic } \\
\text { Mapper Plus } \\
(\text { ETM+) Level-1 }\end{array}$ & $\begin{array}{l}\text { July, } 1999 \\
\text { to present) }\end{array}$ & $\begin{array}{l}(166),(167) \&(168) / \\
(56 \& 57),(55,56 \& 57) \\
\&(55 \& 56)\end{array}$ & 90 & 8 & $\begin{array}{l}\text { January 27, } \\
2002\end{array}$ \\
\hline $\begin{array}{l}\text { Landsat } \\
4-5\end{array}$ & $\begin{array}{l}\text { Thematic Mapper } \\
\text { (TM) Level-1 }\end{array}$ & $\begin{array}{l}\text { July } 1982 \text { to } \\
\text { May } 2012\end{array}$ & $\begin{array}{l}(166),(167) \&(168) /(56 \\
\& 57),(55,56 \& 57) \& \\
(55 \& 56)\end{array}$ & 90 & 7 & $\begin{array}{l}\text { December 18, } \\
1990\end{array}$ \\
\hline
\end{tabular}

\section{Land-Use/Land-Cover Supervised Classification System}

170 Supervised (known spectral signatures) is the process commonly used for quantitative analyses of remote sensing

171 image data and assigns each pixel in the image to which its signature is most comparable categories. Finally, eight

172 types of LULC classes were generated in the study area (Table 2).

173 Table 2 Description of the different LULC classification systems of the Genale watershed

\begin{tabular}{|c|c|c|c|}
\hline $\begin{array}{l}\text { S. } \\
\text { No }\end{array}$ & $\begin{array}{l}\text { LULC } \\
\text { Categories }\end{array}$ & General description of different sub-class included & $\begin{array}{l}\text { SWAT } \\
\text { Code }\end{array}$ \\
\hline 1 & $\begin{array}{l}\text { Shrub/bush } \\
\text { land }\end{array}$ & $\begin{array}{l}\text { Scrubland, brush/bushland, herbs, vegetation types, sparse woodland, } \\
\text { rangelands, orchard stemmed woody plant, and other grasslands }\end{array}$ & RNGB \\
\hline 2 & $\begin{array}{l}\text { Agricultural } \\
\text { land }\end{array}$ & $\begin{array}{l}\text { Farm plantations, croplands, palms, bamboo plantation, terraced land, } \\
\text { vegetable/fruit land, irrigated arid land, wooded/cultivated areas }\end{array}$ & AGRL \\
\hline 3 & Forest & $\begin{array}{l}\text { Reserved and protected forest, mixed forest, deciduous forest, Arboreal } \\
\text { forest, shrubbery area, and economic forest, scrub forest }\end{array}$ & FRST \\
\hline 4 & Built up land & $\begin{array}{l}\text { Towns, villages, buildings, huts, churches, mosques, tombs, graves, post- } \\
\text { office, power lines, transportation roads, bridges }\end{array}$ & URBN \\
\hline 5 & Pasture land & Grassland, savanna, heathland, moorland, machair, rangeland, legumes & PAST \\
\hline 6 & Barren land & $\begin{array}{l}\text { Vacant land, barren rocky, land with/without scrub, Mining/ industrial } \\
\text { wastelands, exposed soil, salt-affected area, and land that cannot be utilized }\end{array}$ & BARR \\
\hline 7 & Water bodies & Lakes, rivers/streams, reservoirs, swamps, springs, canals, ponds, bays, etc. & WATR \\
\hline 8 & Wetlands & Swamps, flora, fauna, coastal lagoons, Inland and maritime wetland & WET \\
\hline
\end{tabular}

176 Accuracy assessment is the most important final step in the image classification process, and the objective is to assess

177 qualitative and quantitative sampling of different pixels effectively into the correct land cover classes. Errors arise 178 when a pixel (or feature) belonging to one class is assigned to another category. In order to execute accuracy

179 assessment precisely, we need to compare two sources of information which include: interpreted land use/cover map 180 image derived from the remote sensing data and reference land use map of high-resolution images or ground truth 
data (google earth pro) (Treitz and Rogan 2004). Accuracy in image classification is influenced by inclusion errors (commission error) and exclusion errors (omission error). The landsat classified imagery needs to be assessed for accuracy before the same could input any hydrological applications.

\section{Error/confusion matrix}

185 A confusion matrix is a square cluster of columns and rows ( $\mathrm{n} \times n$ array where $n$ represents the number of classes) in which each row and column represents one class in the defined map. Error matrix match on a class by class basis, the relationship between land-use map of ground truth data, and the corresponding results of an automated classification on Arc GIS.

Reliability or User's Accuracy corresponds to an error of commission (inclusion); it refers to the probability that a category on the classification image will be correct when used on the ground and a pixel/features designated as a specific class in the land use map is this category. Commission error is the number of spectral signatures mistakenly included in an information class.

User's accuracy $=\frac{\text { Total number of correctly classified pixels in each category }}{\text { Total number of classified pixels of reference category (User's Total) }} * 100 \%$

Producer's accuracy corresponds to an error of omission (exclusion): it is the amount of a land category correctly classified on the classification image or the probability that any feature/pixel of an area on the ground in that class has been correctly classified as such, which indicates how well the training sample sets pixels of a given cover type are classified. Omission error is the number of spectral signatures mistakenly excluded from an information class.

Producer's accuracy $=\frac{\text { Total number of correctly classified pixels in each category }}{\text { Total number of classified pixels of reference category (Producer's Total) }} * 100 \%$

Where: $a_{i i}$ number of samples correctly classified, $a_{i+}$ column total for class $i, a_{+i}$ row total for class $i$.

Overall accuracy: is a measure of accuracy assessment for the entire land use map image across all classes present

202 in the categorized image and is the percentage of correctly categorized samples of a confusion matrix.

Overall accuracy $=\frac{\text { Total number of correctly classified pixel (sum of diagonal elements) }}{\text { Total number of reference pixels (accuracy sites) }} * 100 \%$

Kappa coefficient analysis $\left(\boldsymbol{K}_{\text {hat }}\right)$ is a distinct multivariate technique for accuracy assessment between two maps considering all elements of the confusion matrix and having several advantages over other techniques. Its value ranges from 0 to 1 . If the kappa coefficient is equivalent to 0 , there is no compromise between the classified image and the reference ground truth image, and if it equals 1 , then the categorized image and the reference image are precisely the

208 Khat $=\frac{N \sum_{i=1}^{r} X_{i i}-\left(\sum_{i=1}^{r} X_{i+} * X_{+i}\right)}{N^{2}-\left(\sum_{i=1}^{r} X_{i+}{ }^{*} X_{+i}\right)}=\frac{\text { observed }- \text { Expected }}{1-\text { Expected }}$

209 Where $\mathrm{r}=$ number of columns/rows in the confusion matrix, $X_{i i}$ is the number of the observations in row $i$ and column

$210 \mathrm{i}$ (on the major diagonal), and $X_{i+}$ and $X_{+i}$ are the marginal totals for row i and column i, respectively, and $N$ is the 211 total number of observations included in the matrix.

212 Table 3 Rating criteria of kappa statistics efficiency (Rwanga and Ndambuki 2017)

\begin{tabular}{lll}
\hline ID & Kappa statistics analysis & Strength of the agreement \\
\hline 1 & $<0$ & Poor \\
2 & $0.00-0.20$ & Slight \\
3 & $0.21-0.40$ & Fair \\
4 & $0.41-0.60$ & Moderate
\end{tabular}




\section{Change detection}

This paper aimed to detect and estimate the amount of change from different classified land use maps during the period over (1990-2002, 2002-2013, and 1990-2013) from each other using RS jointly with GIS technique (Esam et al., 2012). LULC change detection was used to identify, characterize, and quantify differences between imageries of the same study area and different periods, while percentage changes were evaluated by dividing it by the total area and multiplying by hundred. The dynamic indicator of land use/cover is used to quantitatively investigate/monitor the change in intensity of one land use type (Yuhai 1999). The value of dynamic index $\mathrm{K}$ is computed as;

224 where $U_{a}$ and $U_{b}$ are the area of a particular land-use/cover type at the beginning (previous) and end (recent) of the study period, respectively, $\mathrm{T}$ is the interval length of period/ the duration of the study (in years), $\mathrm{K}$ is the rate change of area per year of a specific land-use/land-cover categories.

\section{Description of Soil and Water Assessment Tool (SWAT) model}

The SWAT model was developed by a united state department of agriculture research service (USDA-RS). It is a conceptual, physically based, basin-scale, daily time step, a semi-distributed model that operates continuously. The model elements include weather, hydrology, erosion/sedimentation, plant growth, nutrients, pesticides, agricultural management practice, channel routing, and pond/reservoir routing. The model estimations are performed on hydrologic response units (HRUs) basis, flow and water quality variables are routed from HRUs to sub-basin and finally to the watershed outlet. In the land phase of the hydrological system, SWAT simulates the hydrological process based on the water balance equation.

$$
S W_{t}=S W_{o}+\sum_{i=1}^{t}\left(R_{\text {day }}-Q_{\text {surface }}-E_{a}-W_{\text {seep }}-Q_{g w}\right)
$$

Where; $S W_{t}=$ Final soil water content on a day i $(\mathrm{mm} /$ day $), S W_{o}=$ Initial soil water content on day $\mathrm{i}(\mathrm{mm} /$ day $), \mathrm{t}=$ time in days, $R_{\text {day }}=$ amount of precipitation on a day $\mathrm{i}\left(\mathrm{mm} /\right.$ day), $Q_{\text {surface }}=$ amount of surface runoff on a day $\mathrm{i}$ $(\mathrm{mm} /$ day $), E_{a}=$ amount of evapotranspiration on day $\mathrm{i}(\mathrm{mm} /$ day $), W_{\text {seep }}=$ amount of water entering the vadose zone from the soil profile on a day i ( $\mathrm{mm} /$ day), $Q_{g w}=$ amount of return flow on a day $\mathrm{i}(\mathrm{mm} / \mathrm{day})$.

242 The current SWAT model evaluates surface erosion and sediment yield due to runoff for each HRUs using the 243 following equation (MUSLE) (Williams 1975). 
Where; $\mathrm{Q}_{\mathrm{SED}}=$ Sediment yield(ton/ha/day) from specific HRU, $\mathrm{A}_{\text {hru }}=$ Area of $\mathrm{HRU}$ in(ha), $\mathrm{Q}_{\text {Peak }}=$ peak discharge $\left(\mathrm{m}^{3} / \mathrm{s}\right), \mathrm{K}_{\mathrm{USLE}}=$ soil erodibility factor, $\mathrm{C}_{\mathrm{USLE}}=$ Cover and management practice factor, $\mathrm{P}_{\mathrm{USLE}}=$ Conservation support practice factors, $\mathrm{LS}_{\mathrm{USLE}}=$ Topographic factor, $\mathrm{CFRG}=$ Coarse Fragment Factor.

248 SWAT model attempts two techniques for estimating surface runoff $\left(Q_{\text {Surface }}\right)$ : Soil Conservation Service (SCS) 249 curve number procedure (USDA-SCS 1972), and the Green and Ampt infiltration approach (Green 1911; Andualem and Gebremariam 2015). Using daily or sub-daily basis rainfall, SWAT simulates surface runoff and peak runoff rates for each HRUs. For this research, the SCS curve number method was used to evaluate surface runoff because of the unavailability of sub-daily basis data for the Green and Ampt technique. The model further calculates the streamflow in the HRUs/sub-basins as a result of the total daily rainfall using the SCS curve number $(\mathrm{CN})$ method:

$Q_{\text {Surface }}=\frac{\left\{R_{\text {Day }}-0.2 S\right\}^{2}}{\left\{R_{\text {Day }}+0.8 S\right\}} ;$ for $R_{\text {Day }}>0.2 S$

255 The retention parameter(S) and lateral flow prediction by the SWAT model is expressed as;

$\mathrm{CN}=100$; shows zero potential retention (i.e., impervious catchment), $\mathrm{CN}=0$, shows an infinitely abstracting catchment with $\mathrm{S}=\infty$, where; $R_{\text {Day }}=$ daily rainfall $(\mathrm{mm} /$ day), $\mathrm{S}=$ Potential retention $(\mathrm{mm} /$ day $), \mathrm{CN}=$ curve number.

The SUFI-II optimization algorithm in the SWAT-CUP program (Abbaspour et al. 2007) was used for model sensitivity and uncertainty analysis and the necessary calibration/validation process. In SUFI-II, the model input parameters uncertainty is depicted as uniform distributions. On the other hand, output uncertainty is quantified using the 95\% percent prediction uncertainty. The hydrological model performance was assessed using a coefficient of determination $\left(\mathrm{R}^{2}\right)$, Nash Sutcliff Efficiency (NSE), and percent bias (PBIAS).

265 Coefficient of Determination $\left(\mathrm{R}^{2}\right)$

$266 \quad R^{2}=\frac{\left[\sum_{i=1}^{n}\left(Q_{S i}-Q_{s m}\right)\left(Q_{o i}-Q_{o m}\right)\right]^{2}}{\sum_{i=1}^{n}\left(Q_{s i}-Q_{s m}\right)^{2} \sum_{i=1}^{n}\left(Q_{o i}-Q_{o m}\right)^{2}}$

267 Where, $Q_{s i}$ is the simulated value, $Q_{o i}$ is the measured value, $Q_{o m}$ is the average observed value and $Q_{s m}$ - the 268 average simulated value.

where, $Q_{o i}$ is the observed, $Q_{s i}$ is the simulated and $Q_{o m}$ is the observed average values of discharge.

$272 \quad P B I A S=\frac{\sum_{i=1}^{n}\left(Q_{o i}-Q_{S i}\right)}{\sum_{i=1}^{n} Q_{o i}} \times 100 \%$

273 where, $Q_{o i}$ is the observed discharge value and $Q_{s i}$ is the simulated discharge value.

\section{Results and Discussions}


277 The model was built with DEM, land use/cover, soil properties, and slope types for the Genale watershed, which

278 formed 25 sub-basins, $464 \mathrm{HRUs}$ with a drainage area of $54,942 \mathrm{Km}^{2}$. A SWAT hydrological model adequately

279 simulates streamflow, and sediment load typically accounts for the precise calibration/validation of parameters under different year land cover.

\section{Land Use Land Cover Change Analysis}

The LULC change detection map shows eight (shrub/bushland, built up, forest, agriculture, bare land, pastureland, water bodies, and wetlands) categories of LULC through image processing and classification through image processing and classification processing and classification created unifying these classes for 1990, 2002 and 2013. The spatial analysis of LULC has been executed to describe the overall land use cover patterns throughout the catchment. An image was checked with an accuracy matrix using 334 randomly selected control points. The accuracy assessment was achieved using LULC maps and ground truth data on Google Earth Pro (Fig. 3). The supervised classes.
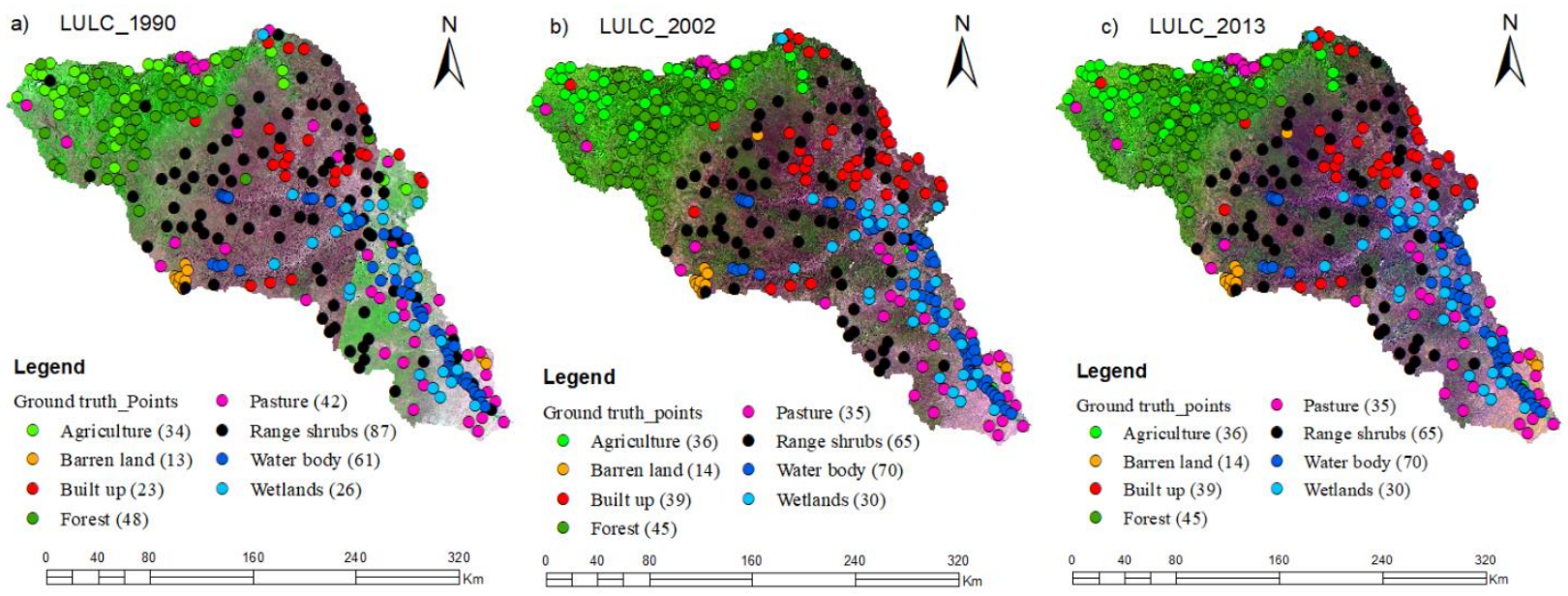

Fig. 3 Image accuracy assessment points (ground truth points) over 1990, 2002, and 2013

Accuracy assessment, planning for future developments with the right decisions, and adequately managing resources requires insightful the location of those resources and their spatial interaction (Congalton and Green 2019). In designing the accuracy assessment sample, this finding utilized randomly selected points for each class of LULC and thus used 334 points for each image (Fig. 3). 
The classification accuracy assessment in terms of Kappa coefficient and error/confusion matrices are essential for classification results to be confident that to what extend the classification is accurate.

305

Table 4 How to summarize and quantify accuracy assessment using confusion matrix for the LULC-2013

\begin{tabular}{|l|l|l|l|l|l|l|l|l|l|l|l|}
\hline & Agriculture & $\begin{array}{l}\text { Barren } \\
\text { land }\end{array}$ & $\begin{array}{l}\text { Built } \\
\text { up }\end{array}$ & Forest & $\begin{array}{l}\text { Pasture } \\
\text { land }\end{array}$ & $\begin{array}{l}\text { Range } \\
\text { shrubs }\end{array}$ & $\begin{array}{l}\text { Water } \\
\text { body }\end{array}$ & Wetland & $\begin{array}{l}\text { User } \\
\text { (Total) }\end{array}$ & $\begin{array}{l}\text { User's } \\
\text { accuracy }\end{array}$ & $\begin{array}{l}\text { Commission } \\
\text { Error }\end{array}$ \\
\hline Agriculture & $\mathbf{3 0}$ & $\mathbf{0}$ & $\mathbf{0}$ & $\mathbf{4}$ & $\mathbf{0}$ & $\mathbf{2}$ & $\mathbf{0}$ & $\mathbf{0}$ & $\mathbf{3 6}$ & $\mathbf{8 3 . 3 3 \%}$ & $\mathbf{1 6 . 6 \%}$ \\
\hline Barren land & $\mathbf{0}$ & $\mathbf{1 3}$ & $\mathbf{0}$ & $\mathbf{0}$ & $\mathbf{1}$ & $\mathbf{0}$ & $\mathbf{0}$ & $\mathbf{0}$ & $\mathbf{1 4}$ & $\mathbf{9 2 . 8 6 \%}$ & $\mathbf{7 . 1 \%}$ \\
\hline Built up & $\mathbf{2}$ & $\mathbf{0}$ & $\mathbf{2 3}$ & $\mathbf{1}$ & $\mathbf{4}$ & $\mathbf{9}$ & $\mathbf{0}$ & $\mathbf{0}$ & $\mathbf{3 9}$ & $\mathbf{5 9 \%}$ & $\mathbf{4 1 \%}$ \\
\hline Forest & $\mathbf{2}$ & $\mathbf{0}$ & $\mathbf{0}$ & $\mathbf{4 1}$ & $\mathbf{0}$ & $\mathbf{2}$ & $\mathbf{0}$ & $\mathbf{0}$ & $\mathbf{4 5}$ & $\mathbf{9 1 . 1 1 \%}$ & $\mathbf{8 . 9 \%}$ \\
\hline Pasture & $\mathbf{0}$ & $\mathbf{0}$ & $\mathbf{0}$ & $\mathbf{0}$ & $\mathbf{3 2}$ & $\mathbf{3}$ & $\mathbf{0}$ & $\mathbf{0}$ & $\mathbf{3 5}$ & $\mathbf{9 1 . 4 \%}$ & $\mathbf{8 . 6 \%}$ \\
\hline Range shrubs & $\mathbf{0}$ & $\mathbf{0}$ & $\mathbf{0}$ & $\mathbf{1}$ & $\mathbf{2}$ & $\mathbf{6 1}$ & $\mathbf{1}$ & $\mathbf{0}$ & $\mathbf{6 5}$ & $\mathbf{9 3 . 8 5 \%}$ & $\mathbf{6 . 1 5 \%}$ \\
\hline Water body & $\mathbf{0}$ & $\mathbf{0}$ & $\mathbf{0}$ & $\mathbf{1}$ & $\mathbf{1}$ & $\mathbf{7}$ & $\mathbf{6 0}$ & $\mathbf{1}$ & $\mathbf{7 0}$ & $\mathbf{8 5 . 7 \%}$ & $\mathbf{1 4 . 2 8 \%}$ \\
\hline Wetlands & $\mathbf{0}$ & $\mathbf{0}$ & $\mathbf{0}$ & $\mathbf{0}$ & $\mathbf{2}$ & $\mathbf{3}$ & $\mathbf{0}$ & $\mathbf{2 5}$ & $\mathbf{3 0}$ & $\mathbf{8 3 . 3 3 \%}$ & $\mathbf{1 6 . 6 7 \%}$ \\
\hline $\begin{array}{l}\text { Producer } \\
\text { (Total) }\end{array}$ & $\mathbf{3 4}$ & $\mathbf{1 3}$ & $\mathbf{2 3}$ & $\mathbf{4 8}$ & $\mathbf{4 2}$ & $\mathbf{8 7}$ & $\mathbf{6 1}$ & $\mathbf{2 6}$ & $\mathbf{3 3 4}$ & & \\
\hline $\begin{array}{l}\text { Producer's } \\
\text { accuracy }\end{array}$ & $\mathbf{8 8 . 2 3 \%}$ & $\mathbf{1 0 0 \%}$ & $\mathbf{1 0 0 \%}$ & $\mathbf{8 5 . 4 \%}$ & $\mathbf{7 6 . 2 \%}$ & $\mathbf{7 0 . 1 \%}$ & $\mathbf{9 8 . 4 \%}$ & $\mathbf{9 6 . 2 \%}$ & & & \\
\hline $\begin{array}{l}\text { Omission } \\
\text { error }\end{array}$ & $\mathbf{1 1 . 8 \%}$ & $\mathbf{0}$ & $\mathbf{0}$ & $\mathbf{1 4 . 6 \%}$ & $\mathbf{2 3 . 8 \%}$ & $\mathbf{2 9 . 8} \%$ & $\mathbf{1 . 6 \%}$ & $\mathbf{3 . 8 5 \%}$ & & & \\
\hline
\end{tabular}

The user and producer accuracy, the results revealed excellent for approximately all the classes in all years except in challenging (Table 4).

$$
\text { Overall accuracy }=\frac{\text { Total number of correctly classified pixel (sum of diagonal elements) }}{\text { Total number of reference pixels (accuracy sites) }} * 100 \%
$$

$$
=\frac{(30+13+23+41+32+61+60+25)}{334} * 100=85 \%
$$

$$
\text { Kappa coefficient }=\frac{N \sum_{i=1}^{r} X_{i i}-\left(\sum_{i=1}^{r} X_{i+} * X_{+i}\right)}{N^{2}-\left(\sum_{i=1}^{r} X_{i+} * X_{+i}\right)}
$$

$$
334 *(30+13+23+41+32+61+60+25)-(34 * 36+
$$

$$
\text { Kappa }=\frac{13 * 14+23 * 39+48 * 45+42 * 35+87 * 65+61 * 70+26 * 30)}{334^{2}-(34 * 36+13 * 14+23 * 39+48 * 45+42 * 35+87 * 65+61 * 70+26 * 30)}=0.828
$$

The value of kappa 0.828 means there is $82.8 \%$ better agreement than by chance only. These values illustrate that the Landsat and the methodologies used were accurate, and the classification is almost perfect since it is greater than 0.8. classifications. Unlike the overall accuracy, the kappa coefficient includes errors of commission and omission. The land use/cover classification has shown that user's Accuracy and producer's Accuracy are greater than 80\%, except in pasture, shrubs, and built up and the overall accuracy of $85 \%$ (Table 4). The results revealed that the overall accuracy of the LULC classification was $77.6 \%, 81.5 \%$, and $85 \%$ for 1990, 2002, and 2013 respectively, and coefficients of kappa for the same years were $74.8 \%, 78.5 \%$, and $82.8 \%$, respectively.

\section{Change detection}


327 registered using the exact spatial resolution viewing spectral bands, geometry, radiometric resolution. Change 328 detection can be characterized as the process of identifying differences in the state of a phenomenon by observing it 329 at different periods 1990, 2002, \& 2013 (Fig. 4).
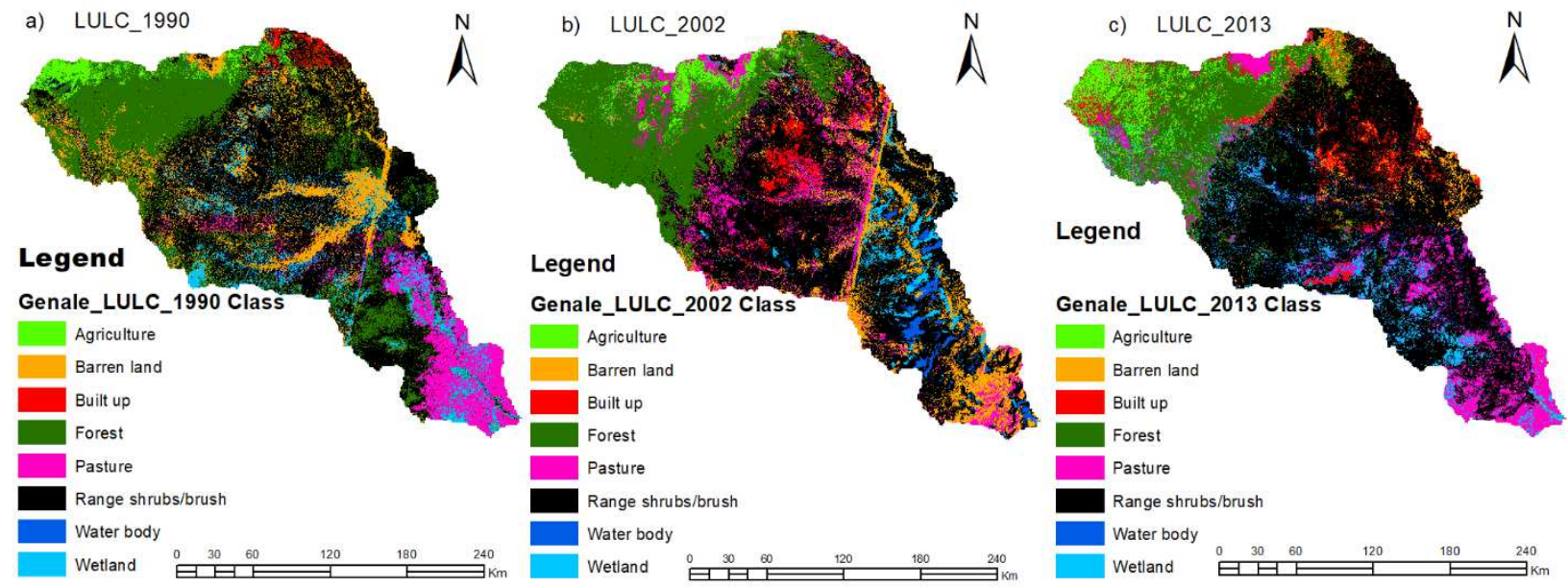

Fig. 4 Land use/cover classification of Genale watershed for the period 1990, 2002, and 2013

Table 5 Summary of the area and relative changes statistics in LULC over 1990 to 2013

\begin{tabular}{|c|c|c|c|c|c|c|c|c|c|c|c|c|c|}
\hline \multirow{2}{*}{$\begin{array}{l}\text { S. } \\
\text { no }\end{array}$} & \multirow[t]{2}{*}{ LULC-Type } & \multicolumn{2}{|l|}{1990} & \multicolumn{2}{|l|}{2002} & \multicolumn{2}{|l|}{2013} & \multicolumn{2}{|c|}{$\begin{array}{l}\text { Change } \\
(1990-2002)\end{array}$} & \multicolumn{2}{|c|}{$\begin{array}{l}\text { Change } \\
(2002-2013)\end{array}$} & \multicolumn{2}{|c|}{$\begin{array}{l}\text { Change } \\
(1990-2013)\end{array}$} \\
\hline & & $\begin{array}{l}\text { Area } \\
\left(\mathrm{Km}^{2}\right)\end{array}$ & $\begin{array}{l}\text { Area } \\
(\%)\end{array}$ & $\begin{array}{l}\text { Area } \\
\left(\mathrm{Km}^{2}\right)\end{array}$ & $\begin{array}{l}\text { Area } \\
(\%)\end{array}$ & $\begin{array}{l}\text { Area } \\
\left(\mathrm{Km}^{2}\right)\end{array}$ & $\begin{array}{l}\text { Area } \\
(\%)\end{array}$ & $\begin{array}{l}\text { Area } \\
\left(\mathrm{Km}^{2}\right)\end{array}$ & $\begin{array}{l}\text { Area } \\
(\%)\end{array}$ & $\begin{array}{l}\text { Area } \\
\left(\mathrm{Km}^{2}\right)\end{array}$ & $\begin{array}{l}\text { Area } \\
(\%)\end{array}$ & $\begin{array}{l}\text { Area } \\
\left(\mathrm{Km}^{2}\right)\end{array}$ & $\begin{array}{l}\text { Area } \\
(\%)\end{array}$ \\
\hline 1 & Agriculture & 1322 & $2 \%$ & 1593 & $3 \%$ & 3288 & $6 \%$ & 271 & $21 \%$ & 1695 & $6 \%$ & 1966 & $60 \%$ \\
\hline 2 & Barren land & 7361 & $13 \%$ & 6442 & $12 \%$ & 3014 & $5 \%$ & -919 & $-11 \%$ & -3428 & $-53 \%$ & -4347 & $-44 \%$ \\
\hline 3 & Built up & 874 & $2 \%$ & 1339 & $2 \%$ & 2730 & $5 \%$ & 465 & $53 \%$ & 1391 & $4 \%$ & 1856 & $68 \%$ \\
\hline 4 & Forest & 13293 & $24 \%$ & 12624 & $23 \%$ & 9216 & $17 \%$ & -670 & $-5 \%$ & -3408 & $-27 \%$ & -4077 & $-44 \%$ \\
\hline 5 & Pasture & 3990 & $7 \%$ & 5146 & $9 \%$ & 6336 & $12 \%$ & 1156 & $29 \%$ & 1190 & $23 \%$ & 2346 & $37 \%$ \\
\hline 6 & Range shrubs & 23902 & $44 \%$ & 24717 & $45 \%$ & 26208 & $48 \%$ & 815 & $4 \%$ & 1491 & $6 \%$ & 2306 & $9 \%$ \\
\hline 7 & Water body & 365 & $1 \%$ & 1040 & $2 \%$ & 858 & $2 \%$ & 675 & $84 \%$ & -182 & $-18 \%$ & 493 & $57 \%$ \\
\hline 8 & Wetland & 3835 & $7 \%$ & 2041 & $4 \%$ & 3292 & $6 \%$ & -1794 & $-47 \%$ & 1251 & $61 \%$ & -543 & $-17 \%$ \\
\hline
\end{tabular}

Table 5 shows all the major classes of LULC of the basin determined in the change analysis. The results revealed that there is a rapid decrease in the forest $(5 \%, 27 \%$, and $44 \%)$, barren land $(11 \%, 53 \%$, and $44 \%)$, wetland $(47 \%, 61 \%$, and 17\%) from 1990-2002, 2002-2013, and 1990-2013 respectively which is due to the conversion of green forest \& barren land into settlement area or fallow lands, and there is a significant increase in built-up (53\%, 4\%, and 68\%), agriculture $(21 \%, 6 \%$, and $60 \%)$, and water body $(84 \%, 18 \%$, and 57\%) from 1990-2002, 2002-2013, and 1990-2013 respectively. From the 1990 land use/cover classes, about $44 \%$ was devoted to range shrubs, whereas agricultural land and plantation shared $2 \%$. The LULC changes include forestation, an increase in wetlands, and changes in agricultural and built-up (Fig. 5). 


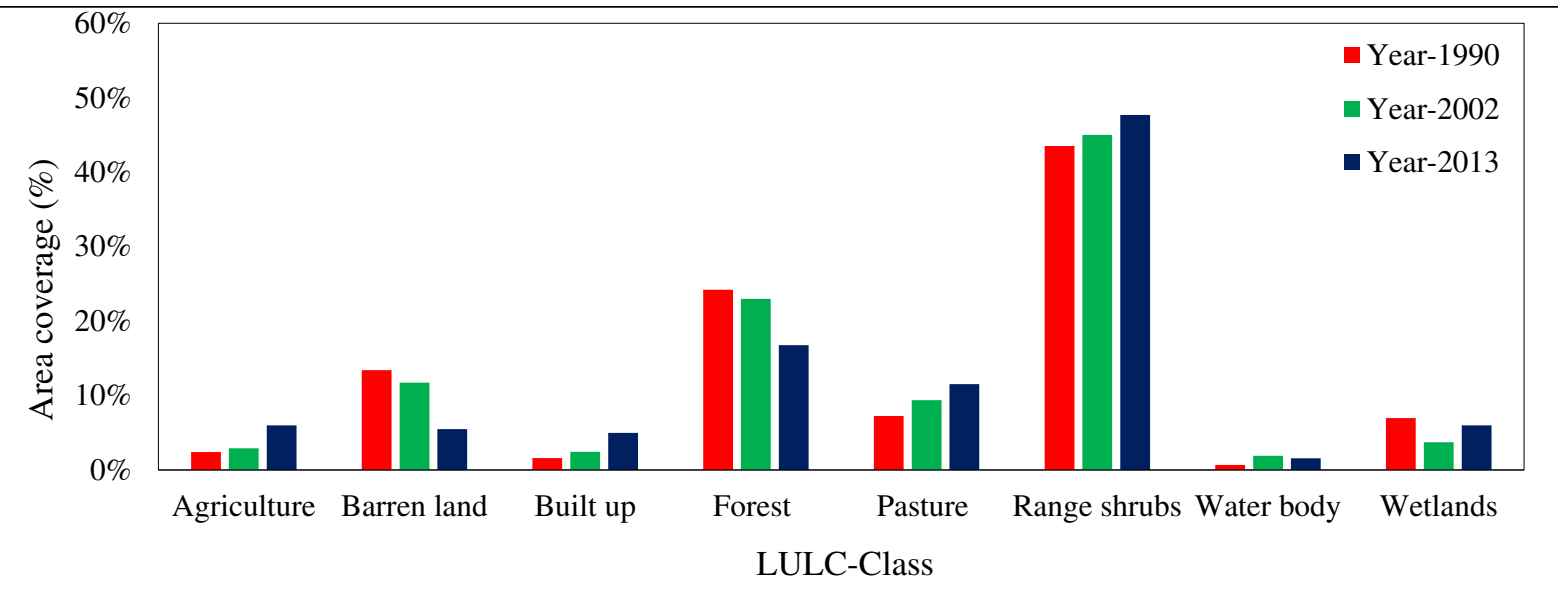

Fig. 5 The dynamics pattern of LULC changes for the years 1990, 2002, and 2013

\begin{tabular}{|c|c|c|c|c|c|c|c|c|}
\hline & & & and use 1 & cover c & e (1990 & 013) & & \\
\hline $70 \%$ & $60 \%$ & & $68 \%$ & & & & $57 \%$ & \\
\hline ○ $50 \%$ & 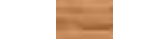 & & & & $37 \%$ & & 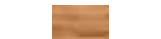 & \\
\hline $30 \%$ & & & & & 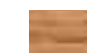 & $9 \%$ & & \\
\hline$\stackrel{50}{\Xi} 10 \%$ & - & & & & & $=$ & $=$ & \\
\hline $\begin{array}{l}\text { ঠै }-10 \% \\
\text { பै -30\% }\end{array}$ & Agriculture & Barren land & Built up & Forest & Pasture & Range shrubs & Water body & $\begin{array}{c}\text { Wetlands } \\
-17 \%\end{array}$ \\
\hline 岕 $-50 \%$ & & $-44 \%$ & & $-44 \%$ & & & & \\
\hline & & & & $0 \mathrm{~V}$ & name & & & \\
\hline
\end{tabular}

Fig. 6 Change in area of LULC between 1990 and 2013 for Genale Basin

Fig. 6 shows the LULC changes that have been taken place in the area through (bar graph) graphical representation. deliberately shows replaced by other land cover changes like built up, agriculture, range shrubs, and pasture land. Nevertheless, the change in a built-up, waterbody, pasture, and agriculture is significantly increased in the catchment by $68 \%, 57 \%, 37 \%$, and 60\%, respectively (Fig. 6).

Impacts of LULC change induced on hydrological responses

\section{Model parameter sensitivity analysis for streamflow and sediment}

359 Sensitivity analysis was performed to navigate the calibration/validation process and identify the optimized parameters that significantly impact the streamflow and sediment load. Sensitivity analyses were conducted based on the global sensitivity produced by the sequential uncertainty fitting version-2 (SUFI-2) algorithm in SWAT CUP. Uncertainty was performed with several iterations of 500 simulations number. Based on the p-value and t-stat values, 10 and 8 
364 parameters. The simulated flow was the most sensitive for the initial SCS curve number II (CN2) and available water

365 capacity (SOL_AWC.sol). Likewise, the simulated sediment was sensitive to the amount of sediment that can be re-

366 entrained during channel sediment routing (SPCON.bsn), (SOL_AWC.sol), CN2, etc.

367 Table 6 Fitted values and rank of parameters used in the SWAT model calibration and validation (1990-2013)

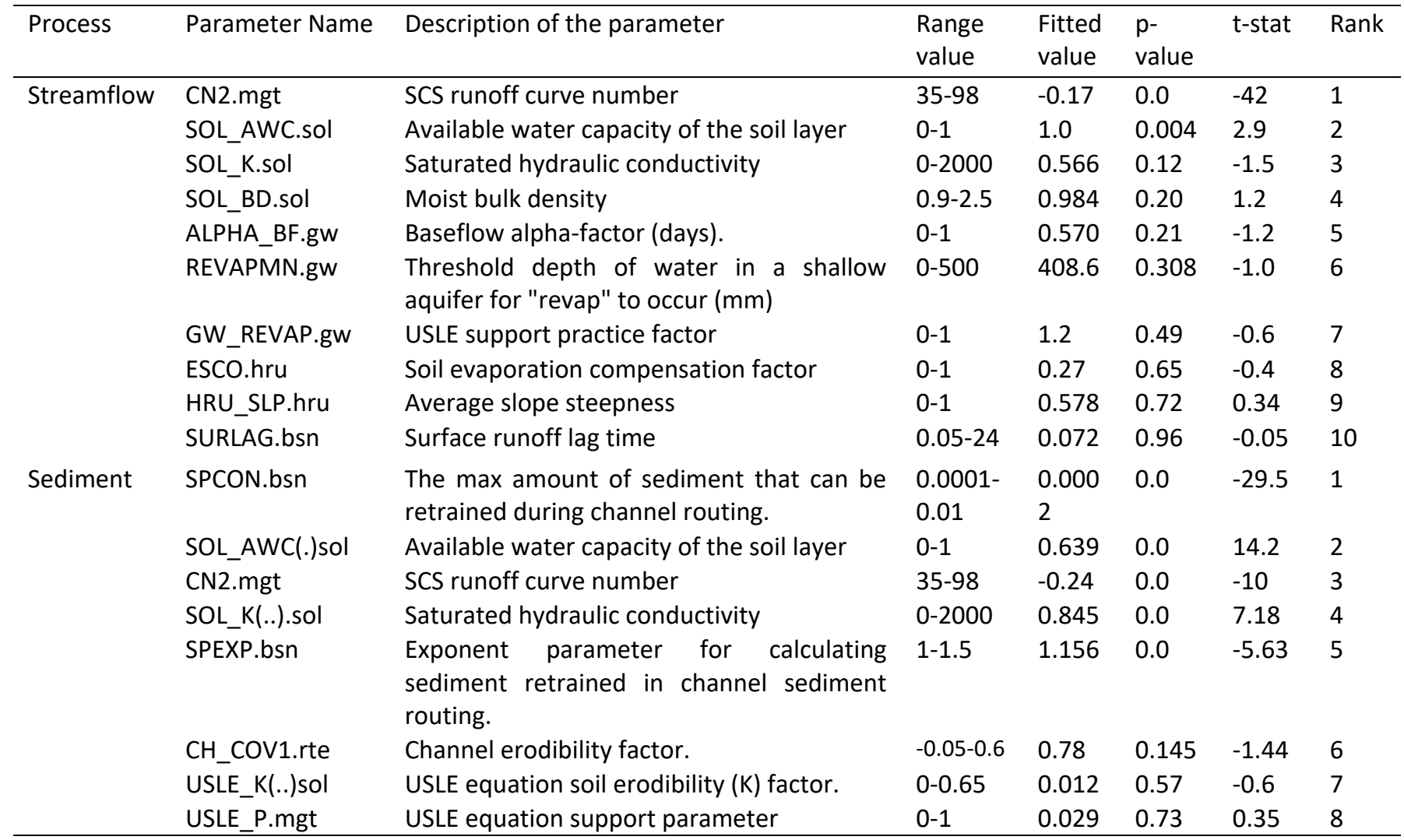

369 Table 6 shows parameter sensitivity results; for example, flow estimation is highly sensitive to CN2.mgt and low

370 sensitivity to GW_REVAP.gw. On the other hand, SPCON.bsn is highly sensitive to sediment flow, and USLE_K.sol

371 is relatively low.

372

\section{Model calibration and validation}

374 Calibrated parameters and the fitted values are the modeler's critical notes from the calibration process. The three

375 years warm-up period 1987 to 1989 analysis of streamflow and sediment load sensitivity was carried out for 16-years

376 calibration period 1990 to 2005 and 8-years validation period 2006 to 2013, and results showed a satisfactory

377 performance, as statistical measures are in the allowable range for both streamflow and Sediment (Table 7)

378

379 Table 7 SWAT statistical performance index acceptable range (Abbaspour et al.,2011; Moriasi et al.,2007)

\begin{tabular}{lllllll}
\hline p-factor & r-factor & R2 & NSE & PBIAS & RSR & Rating
\end{tabular}




\begin{tabular}{|c|c|c|c|c|c|c|c|}
\hline $0.7-1$ & & & & Flow & Sediment & & \\
\hline \multirow{3}{*}{$0.7-1$} & \multirow{3}{*}{$<1,($ close to 0$)$} & $0.75-1$ & $0.75-1$ & $< \pm 10 \%$ & $< \pm 15 \%$ & $0-0.5$ & very good \\
\hline & & $0.65-0.75$ & $0.65-0.75$ & $\pm 10-15 \%$ & $\pm 15-30 \%$ & $0.5-0.6$ & good \\
\hline & & $0.5-0.65$ & $0.5-0.65$ & $\pm 15-25 \%$ & $\pm 30-55 \%$ & $0.6-0.7$ & satisfactory \\
\hline Close to 0 & $>1$, (infinite) & $<0.5$ & $\leq 0.5$ & $> \pm 25 \%$ & $> \pm 55 \%$ & $>0.7$ & unsatisfactory \\
\hline
\end{tabular}

Table 8 Actual index value for SWAT output during calibration/validation process

\begin{tabular}{lllllllll}
\hline \multicolumn{2}{l}{ Types of assessment } & p-factor & r-factor & R2 & NSE & PBIAS & RSR & Rating \\
\hline \multirow{3}{*}{ Flow } & Calibration & 0.51 & 0.78 & 0.87 & 0.81 & $-2.1 \%$ & 0.50 & good \\
\multirow{3}{*}{ Sediment } & Validation & 0.54 & 0.86 & 0.85 & 0.78 & $-0.5 \%$ & 0.52 & good \\
& Calibration & 0.48 & 0.37 & 0.84 & 0.79 & $3.8 \%$ & 0.61 & satisfactory \\
& Validation & 0.43 & 0.39 & 0.82 & 0.75 & $3.9 \%$ & 0.67 & satisfactory \\
\hline
\end{tabular}

Sensitivity measure of SWAT- CUP (SUFI-2) reflected that P-factor of 0.51 and R-factor of 0.78 for calibration and

P-factor of 0.50 and R-factor of 0.86 for validation considering flow (Table 8).

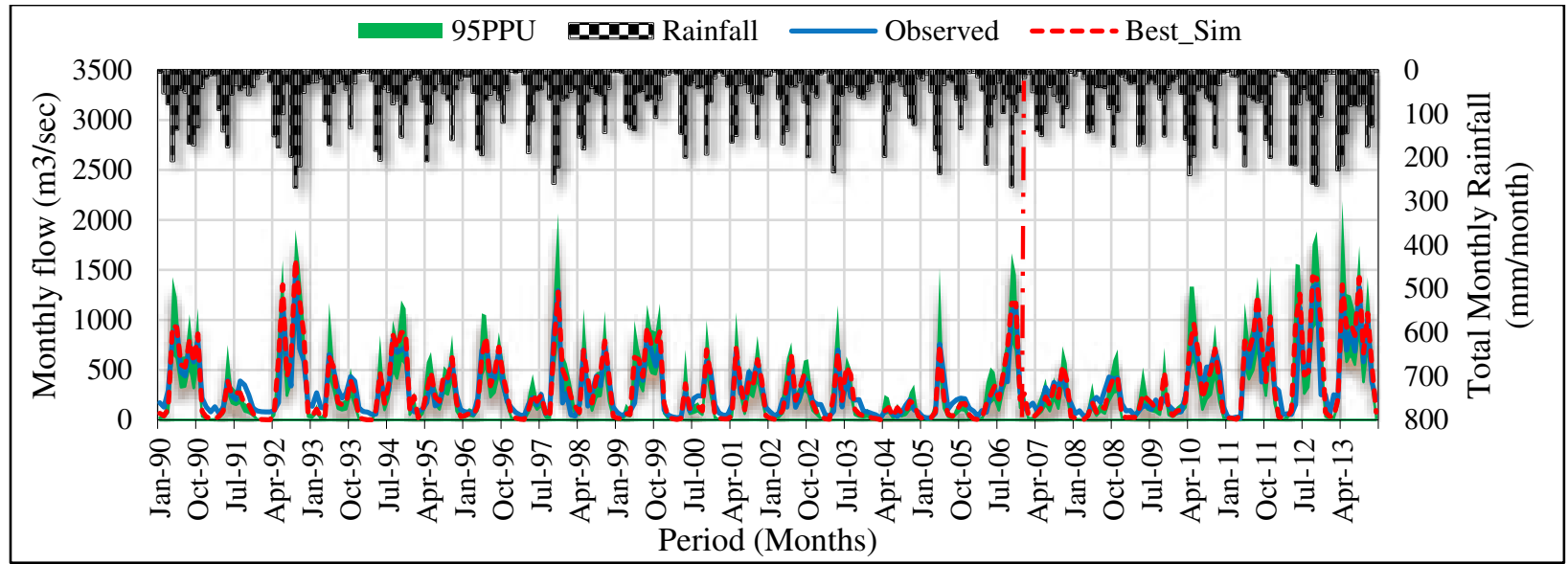

Fig. 7 Monthly observed and simulated hydrograph for the calibration period (1990-2005) and validation (2006-2013)

Fig. 7 shows the calibration and validation of the SWAT model where the model computed values are in good agreement with the monthly observed streamflow.

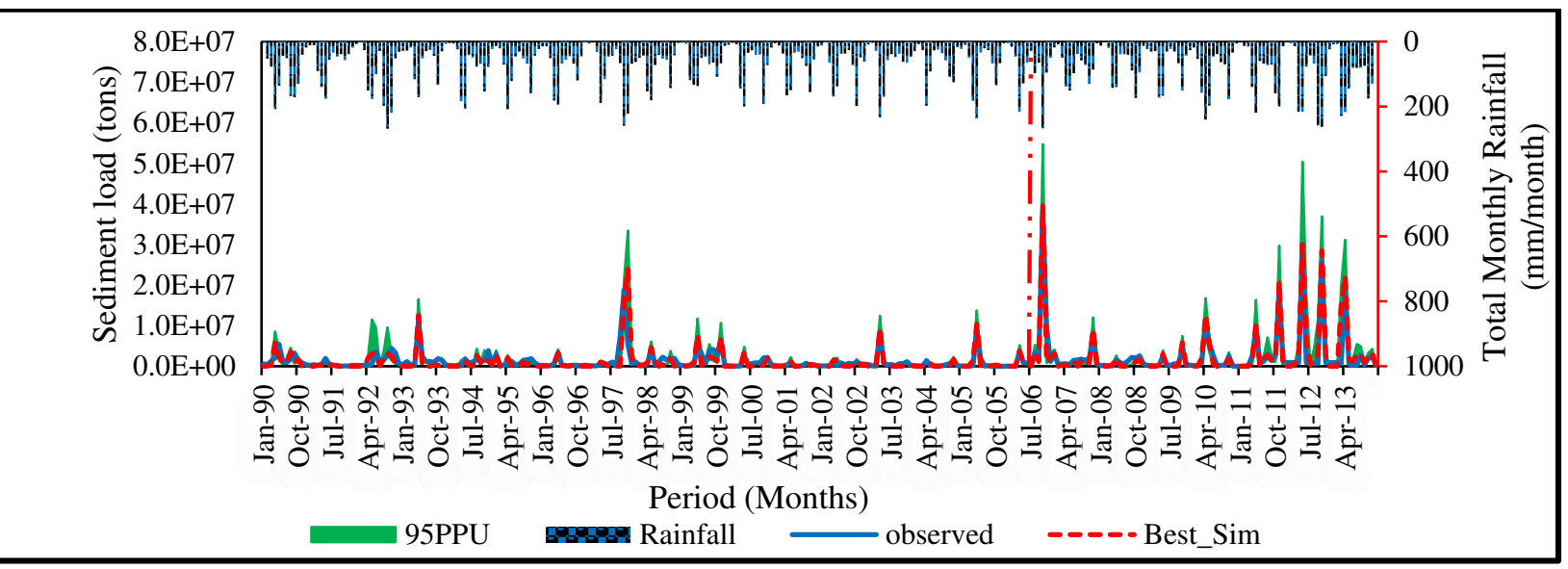

Fig. 8 Monthly observed and simulated sediment load plot for the calibration (1990-2005) and validation (2006-2013). 
393 As shown, the simulated model and observed sediment load and streamflow agreed to show a satisfactory performance during the calibration/validation process (Fig. 7 and 8).

395 The results exhibited that the SWAT model is an essential tool to simulate the spatiotemporal status of hydrological responses about a different period of LULC change due to anthropogenic and socio-economic change in the Genale watershed. The dynamics change in LULC classes between 1990 and 2013 continuously have shifted from the forest, range shrubs, and barren land into agricultural, built up, pasture, and wetlands have significantly contributed to increasing the groundwater flow and water yield while slight reduction of evapotranspiration and surface runoff occurred (Fig. 9). As LULC changes in the study area (1990 to 2013), the generated annual average water balance components also change. The average annual evapotranspiration (ETmm) decreased from 413.85 to $385.2 \mathrm{~mm}$, percolation (PERC) decreased from 408.81 to $383.29 \mathrm{~mm}$, groundwater flow (GW_Qmm) decreased from 377.88 to $366.8 \mathrm{~mm}$, and lateral flow (LAT_Qmm) decreased from 5.3 to $3.65 \mathrm{~mm}$ while surface runoff (SURQmm) increased from 41.85 to $75.8 \mathrm{~mm}$, water yield (WYLDmm) increased from 421.15 to $447.12 \mathrm{~mm}$ (Fig. 9).

405

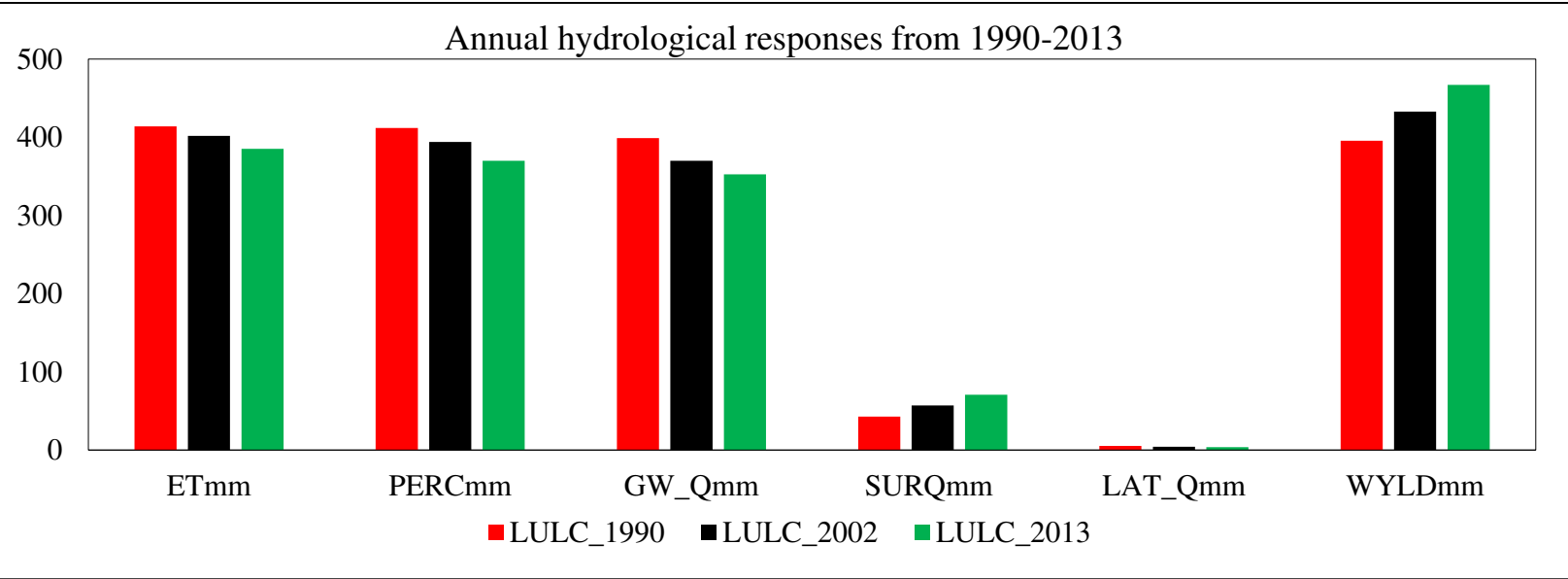

Fig. 9 Average annual hydrological response of for three years LULC map of Genale catchment

The results point out that the consequence of deforestation, agriculture, and settlement in the study area decreased ETmm, which again led to increased surface runoff, sediment yield, and water yield. The groundwater and lateral flow showed a declined trend in the study area (Fig. 9) significantly from 1990 to 2013.

412 The SWAT has classified the catchment into 25 sub-basins. Five were selected as critical based on sediment yield

413 (higher and lower) and forest coverage from these sub-basins. 

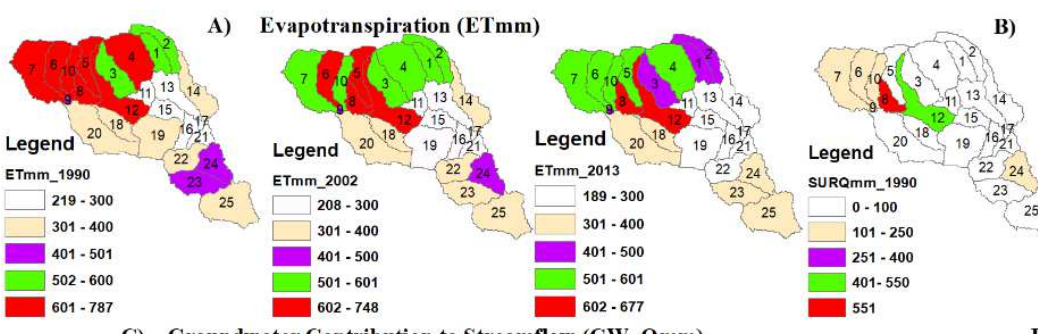

Surface Runoff (SURQmm)

C) Groundwater Contribution to Streamflow (GW Qmm)
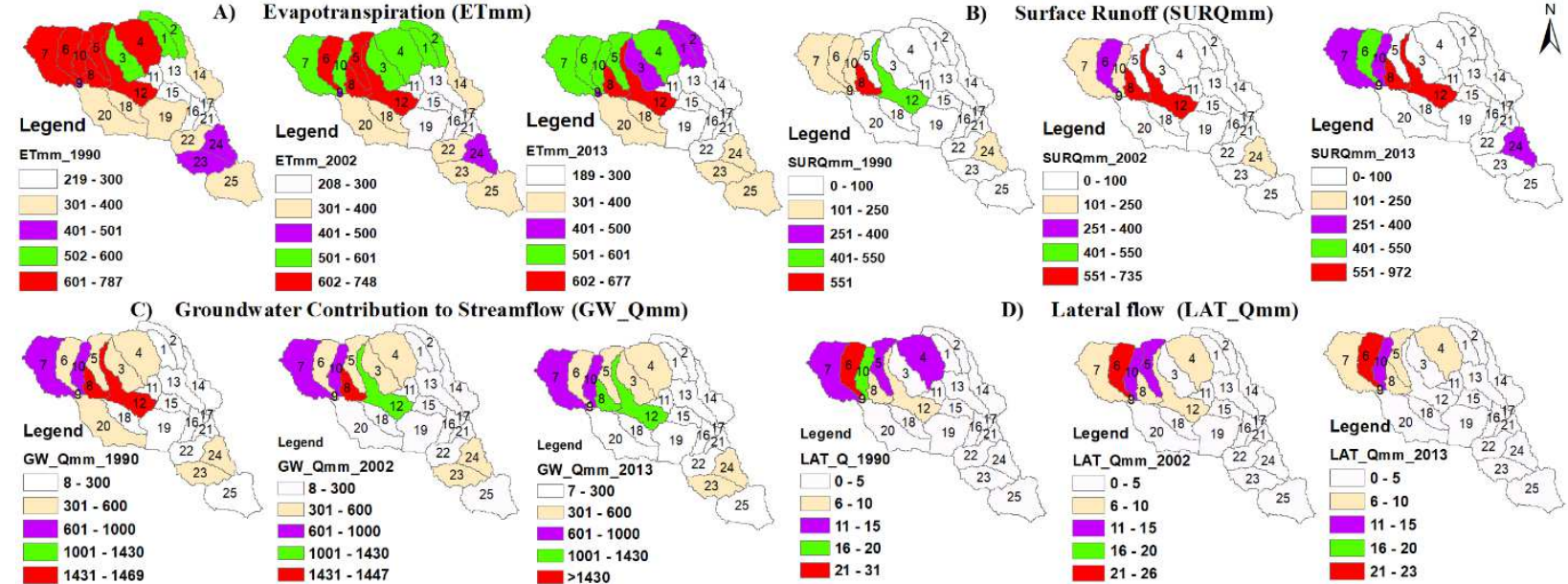

D) Lateral flow (LAT_Qmm)
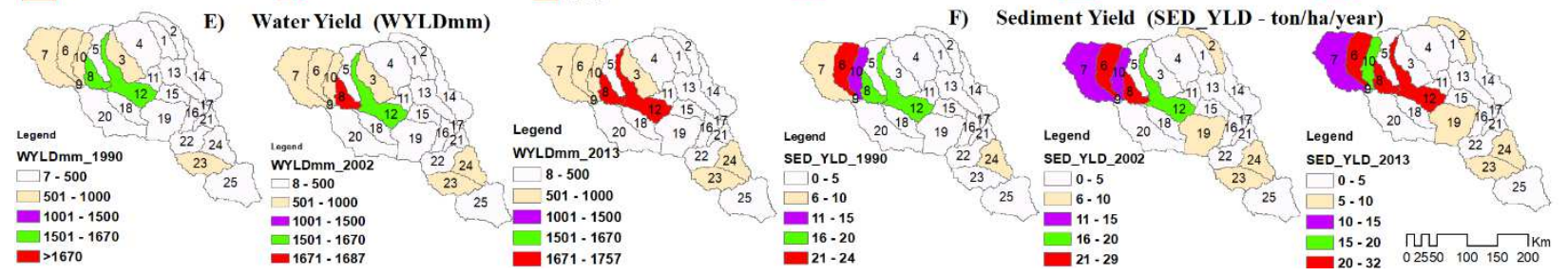

$>1670$

$1501 \cdot 1670$
$-1671 \cdot 1687$

Fig. 10 Spatial variability of hydrological responses at the sub-basin level between LULC maps 1990, 2002, and 2013 in Genale watershed.

The study results revealed an increase in generated surface runoff, water yield, and sediment yield in all indicated subbasins from land use/cover map 1990 to 2013 while evapotranspiration, groundwater flow, and lateral flow are reduced the respective sub-basins. This was due to increased agricultural land, built-up area, pasture land, and decreased forest

422 land and shrubs (Fig. 10). Those sub-catchments having the lowest hydrological responses have made a very small

423 change in land use/cover. Sub-basins 6, 7, 10, 12, and 24 show an increasing surface runoff, and sub-basins 8, 12, and

42424 show an increasing water yield in the watershed from 1990 to 2013 (Fig. 10). Sub-basins 2, 7, 8, 10, 12, 19, and

42523 indicate an increase in sediment yield over different land use maps from 1990 to 2013 (Fig. 10). Evapotranspiration

426 significantly impacted surface runoff in each sub-basin (i.e., higher evapotranspiration contributes to lower surface

427 runoff and vice versa). Based on LULC change, the most significant change in hydrological components is an increase in surface runoff and sediment yield and a decrease in groundwater flow and evapotranspiration, which mainly occurred upstream of the watershed (Fig. 10). 


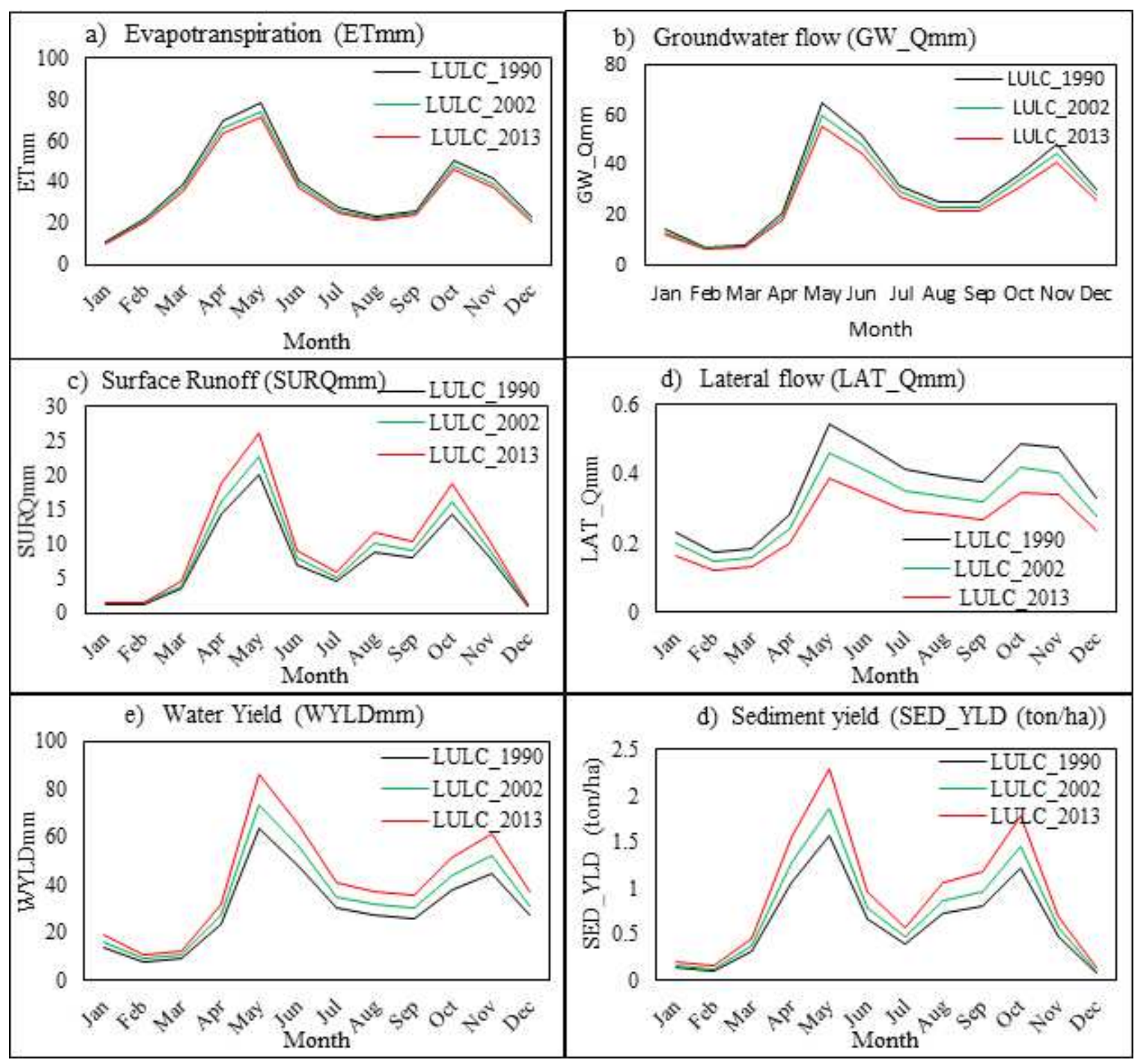

432

Fig. 11 Monthly average (1990-2013) hydrological components in the different LULC periods (1990, 2002, and 2013) of the Genale watershed

434 The monthly time extent of the model shows the ETmm losses, groundwater flow, \& lateral flow are showing a 435 decreasing trend while surface runoff, water yield, and sediment yields are increasing over LULC map 1990, 2002, 436 and 2013 in the catchment (Fig. 11). ETmm was a fundamental water availability determinant because it negatively impacted the generated surface runoff on the $1^{\text {st }}$ and led to water yield and sediment yield. 


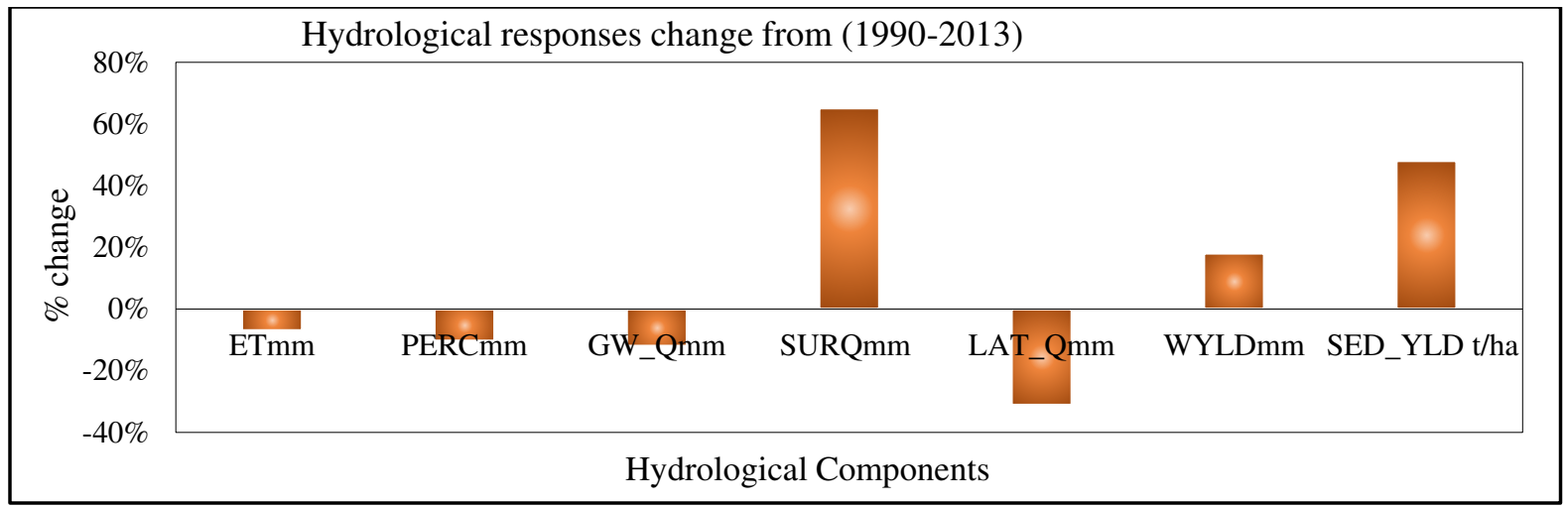

Fig. 12 Hydrological responses relative change under a different period of LULC map (1990 - 2013)

The annual mean catchment evaluates SURQ_mm, GW_mm, WYLDmm, LAT_Qmm, PERCmm, sediment yield, and ET with their relative changes at the watershed outlet under different LULC maps from 1990, 2002, and 2013. Therefore, it reduces infiltration rate due to the top layers of the soil being impervious, resulting in a consistent increase in surface runoff and sediment yield in the catchment (Fig. 12). Comparing the sub-basins scale (Fig. 10) and at the watershed level as a whole (Fig. 12), the impacts of LULC change on the responses of hydrological components are greatly reflected at the sub-basins scale because of the uneven spatial distribution of land cover modification. LULC change impacts were significant at a smaller scale whereas relatively small at the catchment scale due to compensating effects.

\section{Impacts of individual LULC change induced on hydrological responses changes}

Table 9 shows a correlation matrix of eight LULC classes and eight hydrological elements. The results exhibit that approximately all LULC classes have a fair correlation with various hydrological elements. Additionally, appropriate correlations among the hydrological components are also observed. For instance, agricultural land had a positive correlation with surface runoff (0.702), water yield (0.535), and sediment yield (0.348), while the correlation of agriculture with groundwater, lateral flow, percolation, and evapotranspiration is negative (Table 9). On the other hand, the correlation between surface runoff, water yield, and sediment yield is positive, but it is negative between surface runoff and groundwater, between surface runoff and lateral flow, water yield, and evapotranspiration (Table 9). Forest land shows a high correlation with surface runoff, lateral flow, water yield, evapotranspiration with correlation coefficients of $-0.958,+0.759,-0.760$, and +0.729 , respectively.

In contrast, Forest land shows a relatively low correlation with other hydrological elements (Table 9). Generally, from

Table 9, a positive correlation coefficient illustrates that an increase in the first variable would correspond to an increase in the second variable, thus signify a direct relationship between the variables. A negative correlation illustrates an inverse relationship where the first variable increase, the second variable decreases.

Table 9. Correlation matrix for changes in LULC and hydrological responses between 1990 and 2013.

Note: RNGB: range shrubs; AGRL: agriculture; FRST: forest; URBN: built up; PAST: pasture; BARR: barren land; WATR: water body; WET: wetlands; GW_Q: groundwater; SURQ: surface runoff; LAT_Q: lateral flow; PERC: percolation; WYLD: water yield; ET: evapotranspiration; SYLD: sediment yield. 


\begin{tabular}{|c|c|c|c|c|c|c|c|c|c|c|c|c|c|c|c|}
\hline Variables & RNGB & AGRL & FRST & URBN & PAST & BARR & WATR & WET & GW_Q & SURQ & LAT_Q & PERC & WYLD & ET & SYLD \\
\hline RNGB & 1.000 & -0.764 & 0.847 & -0.683 & -0.781 & 0.705 & -0.817 & -0.633 & 0.533 & -0.877 & 0.526 & 0.307 & -0.797 & 0.876 & -0.510 \\
\hline AGRL & & 1.000 & -0.766 & 0.453 & 0.772 & -0.968 & 0.761 & 0.814 & -0.733 & 0.702 & -0.620 & -0.475 & 0.535 & -0.499 & 0.348 \\
\hline FRST & & & 1.000 & -0.532 & -0.601 & 0.785 & -0.698 & -0.624 & 0.497 & -0.958 & 0.759 & 0.591 & -0.760 & 0.729 & -0.578 \\
\hline URBN & & & & 1.000 & 0.145 & -0.259 & 0.199 & 0.723 & -0.691 & 0.495 & 0.129 & 0.346 & 0.174 & -0.867 & -0.180 \\
\hline PAST & & & & & 1.000 & -0.804 & 0.950 & 0.383 & -0.298 & 0.667 & -0.697 & -0.577 & 0.815 & -0.425 & 0.688 \\
\hline BARR & & & & & & 1.000 & -0.814 & -0.704 & 0.614 & -0.718 & 0.778 & 0.663 & -0.608 & 0.374 & -0.488 \\
\hline WATR & & & & & & & 1.000 & 0.482 & -0.407 & 0.697 & -0.728 & -0.571 & 0.808 & -0.444 & 0.637 \\
\hline WET & & & & & & & & 1.000 & -0.986 & 0.453 & -0.193 & 0.004 & 0.130 & -0.512 & -0.171 \\
\hline GW_Q & & & & & & & & & 1.000 & -0.306 & 0.064 & -0.126 & 0.007 & 0.416 & 0.312 \\
\hline SURQ & & & & & & & & & & 1.000 & -0.766 & -0.615 & 0.879 & -0.793 & 0.726 \\
\hline LAT_Q & & & & & & & & & & & 1.000 & 0.966 & -0.807 & 0.223 & -0.857 \\
\hline PERC & & & & & & & & & & & & 1.000 & -0.697 & 0.015 & -0.847 \\
\hline WYLD & & & & & & & & & & & & & 1.000 & -0.610 & 0.921 \\
\hline ET & & & & & & & & & & & & & & 1.000 & -0.313 \\
\hline SYLD & & & & & & & & & & & & & & & 1.000 \\
\hline
\end{tabular}

466
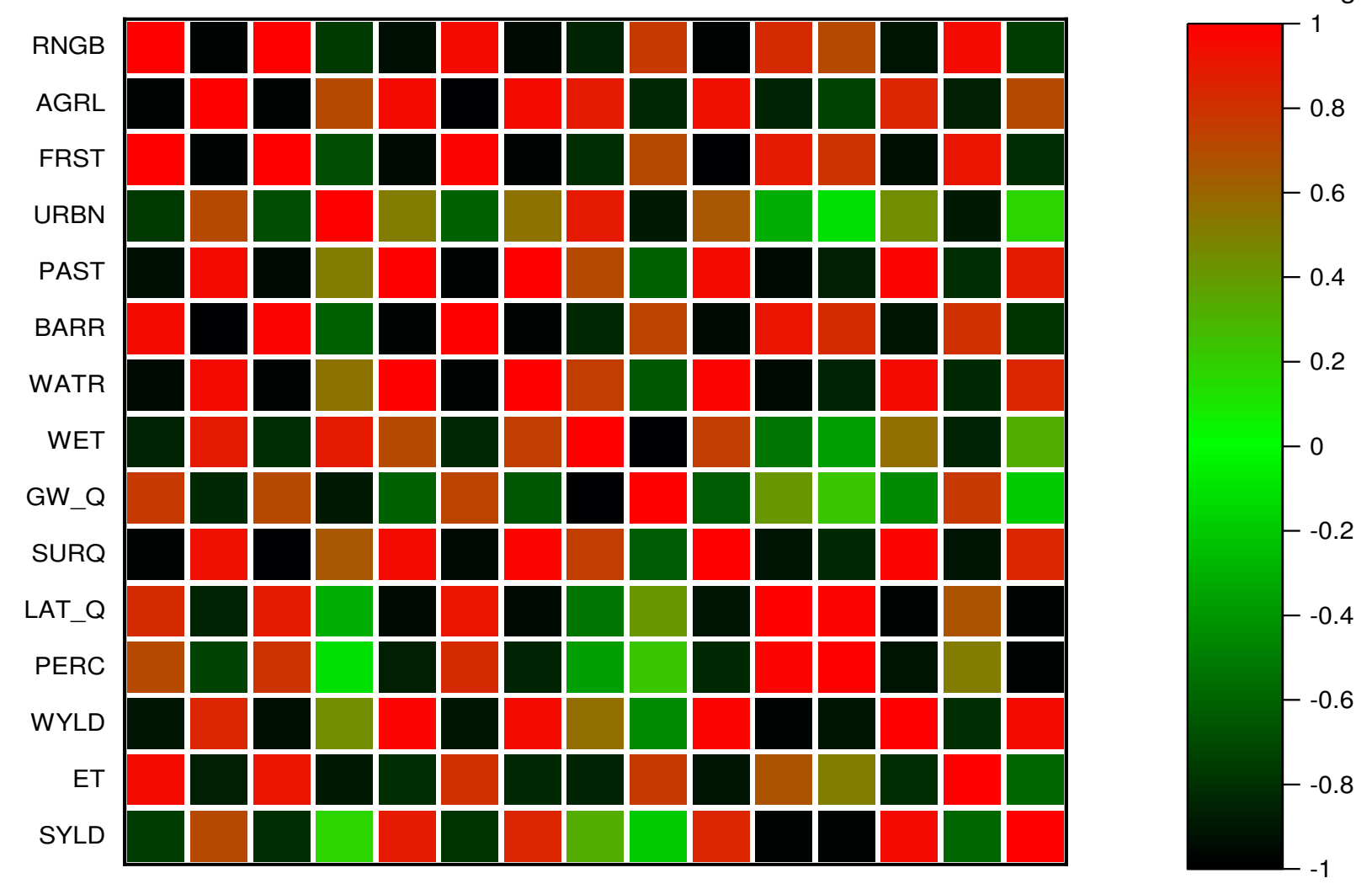

468 Figure 13. Qualitative pictorial heat map showing correlation matrixes of LULC and hydrological components

469 Note: RNGB: range shrubs; AGRL: agriculture; FRST: forest; URBN: built up; PAST: pasture; BARR: barren land;

470 WATR: water body; WET: wetlands; GW_Q: groundwater; SURQ: surface runoff; LAT_Q: lateral flow; PERC:

471 percolation; WYLD: water yield; ET: evapotranspiration; SYLD: sediment yield.

472 The qualitative image of the correlation matrix (Fig. 13) gives a descriptive/visual representation of the induced

473 relationship between LULC types and hydrological elements. A heat map is a qualitative way of data analysis by 
474 visualization to discuss which areas get the most attention, shows you in a visual way which can be easy to assimilate and make decisions.

\section{Conclusions}

Remote sensing (RS) and Geographical information system (GIS) can be a powerful tools to convey good opportunities for integrated analysis of different year spatiotemporal data, image accuracy assessment, mapping, and evaluating LULC change detection process. The dynamic LULC change, notably settlement, forest, wetland, and agricultural areas, is further fancy for obtaining up-to-date information regarding newly constructed houses, cultivating, newly established industries, and commercial developments (human activities and modifications). Despite the observed suspended sediment load data scarcity, the SWAT model showed a good performance in the Genale watershed in predicting sediment load and other hydrological components under different LULC changes. The utmost aim of this work was to determine the significant amount of LULC change taking place in the given study area for a different twelve-year span of 1990 to 2002 and 2002 to 2013. This work simulates hydrological components change impacted in response to different year LULC change induced by anthropogenic activities. The LULC changed by increasing settlements, agriculture, water body by decreasing forest cover and barren lands from 1990 to 2013. Based on an increase in agriculture, built-up, and pasture areas leads to a decline in forest, barren land, and wetlands, the annual mean surface runoff demonstrated a continuously increasing trend, from $43.5 \mathrm{~mm}$ in 1990 to $57.85 \mathrm{~mm}$ in 2002, and to $75.5 \mathrm{~mm}$ in 2013. In contrast, groundwater, lateral flow, percolation, and ETmm showed declining trends. Notably, changes in hydrological elements were observed at the sub-basins scale, mainly associated with the uneven spatial distribution of LULC changes.

The accurate and comprehensive LULC change detection statistics are significant in estimating the rate, pattern, type of LULC changes and developing strategies that reduce environmental impacts to promote the sustainable development of future changes in land use areas. The statistical analysis is used for the correlation matrix of eight LULC classes and eight hydrological elements to evaluate impacts of individual LULC change induced on hydrological responses changes and shows good correlation. This study provides the analysis that deforestation, agriculture, and settlement are the leading cause that should be controlled, and the government should make aware of every human activity. Therefore, continuous, site-specific, demand-driven, and integrated watershed conservation measures are required to arrest the catastrophic consequences of LULC change induced in the Genale watershed.

Authors' Contributions; $1^{\text {st }}$ Author (Tufa Feyissa Negewo): Conceptualizations, methodology, hydrological modeling, formal analysis, investigation, writing original draft preparation. 2nd author (Prof. Arup Kr. Sarma): Critical revision, guidance, and supervision, re-read and approved the final manuscript. All authors contributed equally to the interpretation of the results and provided critical feedback.

\section{Data Availability Statement}


A third party provided streamflow, sediment concentration, and land use/cover data used during the study. Direct request for these materials was made to the institutions as indicated in the Acknowledgments. Some used data during the study were available online. The DEM was downloaded from USGS Earth Explorer (http://earthexplorer.usgs.gov/) SRTM (Shuttle Radar Topography Mission), and the soil map used in this study was from the Food and Agricultural Organization (FAO), the World Digital Soil Map (http://www.fao.org/ geo network/srv/en /metadata) at the scale 1/5000000 for 2007.

\section{Declarations}

Ethical Approval: The authors certify that all ethical measures fixed by the journal have been respected. We also declare that: this manuscript was not submitted to any other journal, original, and has not been published elsewhere in any form or language (partially or in full).

Conflict of interest/Competing interest: There is a declaration from the authors that there is no conflict of interest associated with this work.

\section{References}

Abbaspour, K. C. (2011). User Manual for SWAT-CUP: SWAT Calibration and Uncertainty Analysis Programs. Eawag: Swiss Fed. Inst. of Aquat. Sci. and Technol., Duebendorf, Switzerland, 103.

Abburu, S., \& Golla, S. B. (2015). Satellite image classification methods and techniques: A review. International journal of computer applications, 119(8).

Abdelkareem, O. E. A., Elamin, H. M. A., Eltahir, M. E. S., Adam, H. E., Elhaja, M. E., Rahamtalla, A. M., ... \& Elmar, C. (2017). Accuracy Assessment of Land Use Land Cover in Umabdalla Natural Reserved Forest, South Kordofan, Sudan. International Journal of Agricultural and Environmental Sciences, 3, 5-9.

Adam, P. H. E. (2011). Integration of remote sensing and GIS in studying vegetation trends and conditions in the gum Arabic belt in North Kordofan, Sudan.

Andualem, T. G., \& Gebremariam, B. (2015). Impact of land use land cover change on streamflow and sediment yield: a case study of Gilgel Abay watershed, Lake Tana sub-basin, Ethiopia. Int. J. Technol. Enhanc. Merg. Eng. Res, 3, $28-42$.

Aragaw, H. M., Goel, M. K., \& Mishra, S. K. (2021). Hydrological responses to human-induced land use/land cover changes in the Gidabo River basin, Ethiopia. Hydrological Sciences Journal, 66(4), 640-655.

Bharatkar, P. S., \& Patel, R. (2013). Approach to accuracy assessment tor RS image classification techniques. International Journal of Scientific \& Engineering Research, 4(12), 79-86.

Campbell, J. B., \& Wynne, R. H. (2011). Introduction to remote sensing. Guilford Press.

Choto, M., \& Fetene, A. (2019). Impacts of land use/land cover change on streamflow and sediment yield of Gojeb watershed, Omo-Gibe basin, Ethiopia. Remote Sensing Applications: Society and Environment, 14, 84-99.

Congalton, R. G., \& Green, K. (2019). Assessing the accuracy of remotely sensed data: principles and practices. CRC press.

Coppin, P., Jonckheere, I., Nackaerts, K., Muys, B., \& Lambin, E. (2004). Review article digital change detection methods in ecosystem monitoring: a review. International journal of remote sensing, 25(9), 1565-1596.

El Harraki, W., Ouazar, D., Bouziane, A., El Harraki, I., \& Hasnaoui, D. (2021). Streamflow Prediction Upstream of a Dam Using SWAT and Assessment of the Impact of Land Use Spatial Resolution on Model Performance. Environmental Processes, 1-22. Elimy, E. A., Hassan, A. A., Omar, M. A., Nasser, G. A. E., \& Riad, P. H. (2020). Land Use/Land Cover Change Detection Analysis for Eastern Nile Delta Fringes, Egypt. 
Erasu, D. (2017). Remote sensing-based urban land use/land cover change detection and monitoring. Journal of Remote Sensing \& GIS, 6(2), 5.

Esam, I., Abdalla, F., \& Erich, N. (2012). Land use and land cover changes of west tahta region, sohag governorate, Upper Egypt. Gashaw, T., Tulu, T., Argaw, M., \& Worqlul, A. W. (2018). Modeling the hydrological impacts of land use/land cover changes in the Andassa watershed, Blue Nile Basin, Ethiopia. Science of the Total Environment, 619, 1394-1408.

Green, W. H. (1911). Ampt. GA: Studies on soil physics. 1. Flow of air and water through soils. J. Agr. Sci, 4, 1-24.

Guse, B., Pfannerstill, M., \& Fohrer, N. (2015). Dynamic modelling of land use change impacts on nitrate loads in rivers. Environmental Processes, 2(4), 575-592.

Gwenzi, W., \& Nyamadzawo, G. (2014). Hydrological impacts of urbanization and urban roof water harvesting in water-limited catchments: a review. Environmental Processes, 1(4), 573-593.

Harris, A., Carr, A. S., \& Dash, J. (2014). Remote sensing of vegetation cover dynamics and resilience across southern Africa. International Journal of Applied Earth Observation and Geoinformation,28, 131-139. https://doi.org/10.1016/j.jag.2013.11.014

Huang, T. C., \& Lo, K. F. A. (2015). Effects of land-use change on sediment and water yields in Yang Ming Shan National Park, Taiwan. Environments, 2(1), 32-42.

Hussain, S., Mubeen, M., Ahmad, A., Akram, W., Hammad, H. M., Ali, M., ... \& Nasim, W. (2019). Using GIS tools to detect the land use/land cover changes during forty years in Lodhran district of Pakistan. Environmental Science and Pollution Research, $1-17$.

Kaya, İ. A., \& Görgün, E. K. (2020). Land use and land cover change monitoring in Bandırma (Turkey) using remote sensing and geographic information systems. Environmental Monitoring and Assessment, 192(7), 1-18.

Kumar, N., Singh, S. K., Srivastava, P. K., \& Narsimlu, B. (2017). SWAT Model calibration and uncertainty analysis for streamflow prediction of the Tons River Basin, India, using Sequential Uncertainty Fitting (SUFI-2) algorithm. Modeling Earth Systems and Environment, 3(1), 30.

Li, Y., \& DeLiberty, T. (2020). Assessment of urban streamflow in historical wet and dry years using SWAT across Northwestern delaware. Environmental Processes, 7(2), 597-614.

Manjunatha, M. C., \& Basavarajappa, H. T (2020). Mapping of Land units \& its Change Detection Analysis in Chitradurga taluk of Karnataka State, India, using Geospatial Technology. International Advanced Research Journal in Science, Engineering \& Technology, 7(7), 61-68.

Moriasi, D. N., Arnold, J. G., Van Liew, M. W., Bingner, R. L., Harmel, R. D., \& Veith, T. L. (2007). Model evaluation guidelines for systematic quantification of accuracy in watershed simulations. Transactions of the ASABE, 50(3), 885-900.

Navin, M. S., \& Agilandeeswari, L. (2019). Land use land cover change detection using k-means clustering and maximum likelihood classification method in the javadi hills, Tamil Nadu, India. International Journal of Engineering and Advanced Technology (IJEAT).

Negewo, T. F., \& Sarma, A. K. (2021a). Estimation of Water Yield under Baseline and Future Climate Change Scenarios in Genale Watershed, Genale Dawa River Basin, Ethiopia, Using SWAT Model. Journal of Hydrologic Engineering, $26(3), 05020051$. DOI. (10.1061/(ASCE)HE.1943-5584.0002047).

Negewo, T. F., \& Sarma, A. K. (2021b). Evaluation of Climate Change-Induced Impact on Streamflow and Sediment Yield of Genale Watershed, Ethiopia (DOI: https://www.intechopen.com/books/10754; DOI:10.5772/intechopen.98515). In: Stuart Harris. Global Warming and Climate Change. London, UK: intechopen, 1-21.

Negewo, T. F., \& Sarma, A. K. (In press). Spatial and Temporal Variability Estimation of Sediment Yield and Subbasins/Hydrologic Response Units Prioritization on Genale Basin, Ethiopia. Journal of Hydrology /HYDROL38701. 
Negewo, T. F., \& Sarma, A. K. (In press). Sustainable and Cost-Effective Management of Degraded Sub-Watersheds Using Ecological Management Practices (EMPs) for Genale Basin, Ethiopia. Hydrological Sciences Journal - HSJ-2021-0171.

Pettorelli, N., Chauvenet, A. L., Duffy, J. P., Cornforth, W. A., Meillere, A., \& Baillie, J. E. (2012). Tracking the effect of climate change on ecosystem functioning using protected areas: Africa as a case study. Ecological Indicators, 20, $269-276$.

Rahman, M. T. U., Tabassum, F., Rasheduzzaman, M., Saba, H., Sarkar, L., Ferdous, J., ... \& Islam, A. Z. (2017). Temporal dynamics of land use/land cover change and its prediction using CA-ANN model for southwestern coastal Bangladesh. Environmental monitoring and assessment, 189(11), 1-18. https://doi.org/10.1007/s10661-017-6272-0

Rwanga, S. S., \& Ndambuki, J. M. (2017). Accuracy assessment of land use/land cover classification using remote sensing and GIS. International Journal of Geosciences, 8(04), 611.

Sansare, D. A., \& Mhaske, S. Y. (2020, June). Land-use change mapping and its impact on stormwater runoff using Remote sensing and GIS: a case study of Mumbai, India. In IOP Conference Series: Earth and Environmental Science (Vol. 500, No. 1, p. 012082). IOP Publishing.

Shawul, A. A., Chakma, S., \& Melesse, A. M. (2019). The response of water balance components to land cover change based on hydrologic modeling and partial least squares regression (PLSR) analysis in the Upper Awash Basin. Journal of Hydrology: Regional Studies, 26, 100640.

Tadesse, W., Whitaker, S., Crosson, W., \& Wilson, C. (2015). Assessing the impact of land-use land-cover change on stream water and sediment yields at a watershed level using SWAT_Open Journal of Modern Hydrology, 5(03), 68.

Tomar, S., Saha, A., Kumari, M., \& Somvanshi, S. (2017). Land use and land cover change monitoring of Surajpur Wetland, Uttar Pradesh: using GIS and remote sensing techniques. In 17th Esri India User Conference 2017 (pp. 19-20).

Treitz, P., \& Rogan, J. (2004). Remote sensing for mapping and monitoring land-cover and land-use change-an an introduction. Progress in planning, 61(4), 269-279.

Van Rompaey, A. J., Govers, G., \& Puttemans, C. (2002). Modelling land use changes and their impact on soil erosion and sediment supply to rivers. Earth surface processes and landforms, 27(5), 481-494.

Willams, J. R. (1975). Sediment-yield prediction with a universal equation using runoff energy factor. Present and prospective technology for predicting sediment yields and sources.

Yuhai, W. X. B. (1999). Study on the methods of land uses dynamic change research [J]. Progress in geography, 1. 